\title{
Reconstructing two millennia of copper and silver metallurgy in the Lake Titicaca region (Bolivia/Peru) using trace metals and lead isotopic composition
}

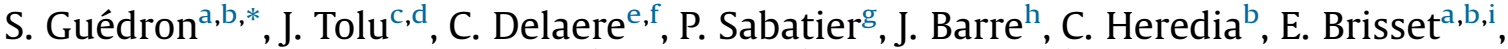 \\ S. Campillo ${ }^{\mathrm{a}}$, R. Bindler ${ }^{\mathrm{j}}$, S.C. Fritz ${ }^{\mathrm{k}}$, P.A. Baker ${ }^{\mathrm{l}}$, D. Amouroux ${ }^{\mathrm{h}}$ \\ a Univ. Grenoble Alpes, Univ. Savoie Mont Blanc, CNRS, IRD, IFSTTAR, ISTerre, 38000, Grenoble, France \\ ${ }^{\mathrm{b}}$ Laboratorio de Hidroquímica, Instituto de Investigaciones Químicas, Universidad Mayor de San Andres, Campus Universitario de Cota Cota, casilla 3161, La \\ Paz, Bolivia \\ ${ }^{c}$ Eawag, Swiss Federal Institute of Aquatic Science and Technology, $\mathrm{CH}-8600$, Dübendorf, Switzerland \\ d ETH Zürich, Universitätstrasse 16, CH-8092, Zürich, Switzerland \\ e Oxford Centre for Maritime Archaeology (OCMA), University of Oxford, OX1 2PG, United Kingdom \\ ${ }^{\mathrm{f}}$ Centre de Recherches en Archéologie et Patrimoine, Université libre de Bruxelles (ULB), 1050, Brussels, Belgium \\ ${ }^{g}$ Univ. Grenoble Alpes, Univ. Savoie Mont Blanc, CNRS, EDYTEM, 73000, Chambéry, France \\ ${ }^{\mathrm{h}}$ Univ. de Pau et des Pays de l'Adour, E2S UPPA, CNRS, IPREM, Institut des Sciences Analytiques et de Physico-chimie pour l'Environnement et les Matériaux, \\ Pau, France

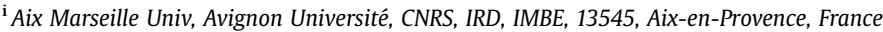 \\ ${ }^{\mathrm{j}}$ Department of Ecology and Environmental Science, Umeå University, Sweden \\ ${ }^{\mathrm{k}}$ Department of Earth and Atmospheric Sciences, University of Nebraska - Lincoln, Lincoln, NE, USA \\ ${ }^{1}$ Division of Earth and Ocean Sciences, Duke University, Durham, NC, USA
}

\section{A R T I C L E I N F O}

\section{Article history:}

Received 5 May 2020

Received in revised form 10 February 2021

Accepted 13 March 2021

Available online 16 March 2021

\section{Keywords:}

Central Andes mining

Lake Titicaca sediment

Copper

Silver

Lead isotopes

\begin{abstract}
A B S T R A C T
Copper, silver, and gold exploitation has been a foundation of economic and socio-cultural development of Andean societies, at least for the last three millennia. The main centers of pre-colonial metallurgy are well-known from archeological artifacts, but temporal gaps inherent in this record handicap a finer understanding of the modalities of ore exploitation by succeeding civilizations. A continuous record over time of trace metals emitted during ore smelting operations make lake sediments excellent candidates to fill those gaps. Two millennia of metallurgy were reconstructed from atmospherically derived metals together with lead $(\mathrm{Pb})$ isotope ratios in two dated sediment cores from Lake Titicaca. The first evidence for metallurgy is found during the apogee of the Tiwanaku state (AD 800-1150), with a higher copper (Cu) accumulation that can be attributed to the smelting of local $\mathrm{Cu}$ ores, based on $\mathrm{Pb}$ isotopic fingerprinting. During the Late Intermediate Period (AD 1150-1450), recorded peaks in metal deposition that persisted for $\sim$ twenty years show that mining activities were intensive but discontinuous. $\mathrm{Pb}$ isotope ratios suggest diversified extractive activities, mainly located in the southern part of the central Altiplano. Finally, the most intense mining epoch began during the Inca Empire (ca. AD 1500) and lasted until the end of the Colonial Period (AD 1830), with unprecedented metal deposition over this interval. Pb isotope fingerprinting shows that mining operations occurred mainly in the Lake Titicaca and Potosi areas and were responsible for metal emissions recorded in the entire Altiplano, as evidenced by other studies.
\end{abstract}

(c) 2021 Elsevier Ltd. All rights reserved.

\section{Introduction}

Metallurgy was initiated at least three millennia ago in the central Andes (Aldenderfer et al., 2008; Cooke et al., 2008a, a),

\footnotetext{
* Corresponding author at: Univ. Grenoble Alpes, Univ. Savoie Mont Blanc, CNRS, IRD, IFSTTAR, ISTerre, 38000, Grenoble, France.

E-mail address: stephane.guedron@ird.fr (S. Guédron).
}

which has some of the richest metal deposits in the world. Archeological studies have reported a sophisticated precolonial metallurgy mostly developed around copper ( $\mathrm{Cu}$ ) alloys (Lechtman, 1984). Silver (Ag) and gold (Au) were also extracted for the production of ritual and ornamental objects, which played a role in the formation of states (Delaere et al., 2019) and in the prestige economy, because precious metals were not monetized prior to Spanish contact (Cesareo et al., 2011; Schultze et al., 2016). 
Within the Andean area occupied by pre-Columbian civilizations, Lake Titicaca is one of the most emblematic sites. It is the original place of the Tiwanaku civilization (AD 600-1150) and was occupied afterward by the Inca ( $A D \sim 1450$ to 1532). Located on the southern shore of the lake, the monumental eponymous site of Tiahuanaco required large quantities of metals for its construction [e.g., tools and architectural cramps (Lechtman, 2003)]. The Tiwanaku Period, also called the Middle Horizon (ca. AD 600-1150), was an interval when the copper industry in the central Andes flourished. It also included the development of tin bronze metallurgy in northern Bolivia and was contemporaneous with the widespread use of arsenic bronze metallurgy in nearby southern Peru (Wari Culture) and northwest Argentina (Lechtman, 2003, 2014).

Before the arrival of the Spaniards, metals were mostly smelted using wind-drafted furnaces (Cooke et al., 2011), which emitted metals contained in the ores at local [e.g., $\mathrm{Cu}$, zinc ( $\mathrm{Zn})$ and antimony ( $\mathrm{Sb})$ ] and regional [e.g., mercury $(\mathrm{Hg})$ and $\mathrm{Pb}$ ] scales depending on their respective residence time in the atmosphere (Buchauer, 1973; Elbaz-Poulichet et al., 2020; Kistler et al., 1987). Evidence of early regional copper metallurgy in the central Andes is found in several ice and lake sediment metal records from Bolivia and Peru, which show distinct $\mathrm{Cu}$ and $\mathrm{Pb}$ enrichments during the first millennium AD (i.e., Tiwanaku/Wari - AD 600-1150), the Late Intermediate Period (AD 1150-1450), and the Inca Empire (Cooke et al., 2007, 2009b; Eichler et al., 2017; Uglietti et al., 2015). At the arrival of the Inca (ca. AD 1450), an increase in mining activities occurred in the Potosi region, with an acceleration after the arrival of the Spaniards (AD 1532), when silver metallurgy became predominant, using processing mainly by smelting or by amalgamation with mercury (Abbott and Wolfe, 2003; Guerrero, 2012, 2016). Lead isotopes have been used worldwide to fingerprint the sources of metal ores used in the production of ancient civilization artifacts (Hirao and Ro, 2013; Macfarlane and Lechtman, 2014; Weeks et al., 2009; Yener et al., 1991). In the central Andes, the strong west to east variation of ore lead isotope ratios, as a function of their distance from the Peru-Chile trench, allows lead sources to be differentiated along the altitudinal ecozonation [i.e., coast, low western Andean slopes, high Andes, and Altiplano (Aitcheson et al., 1995; Macfarlane and Lechtman, 2014)]. Thus, previous geoarchaeological studies have succeeded in identifying the sources of the ores used to make the artifacts (Macfarlane and Lechtman, 2014).

In view of the current knowledge of historical mining in the central Andes, this paper addresses the following research questions and hypotheses $(\mathrm{H})$ :

1 What does the record of trace-metal accumulation in the sediments of Lake Titicaca indicate about the history of metal mining in the tropical Andes, and the duration and intensity of regional mining in the successive civilizations that occupied the region?

H1a. The earliest evidence for mining occurred in the Tiwanaku Period, when power and trade were first consolidated under a single polity that extended widely across the region.

H1b. Mining became more extensive and continuous as population size grew and power became centralized during the Inca and subsequent Colonial Periods.

2 How did the locations of mining change over time in association with successive civilizations that differed in their political structure and technological and material culture?

H2a. Lead isotopic signatures recorded in the sediments of Lake Titicaca can be matched to different regional ore sources and used together with archeological artifacts to identify mining locations.

H2b. The type and location of extracted metals changed overtime depending on the needs (e.g., constructions, arms,

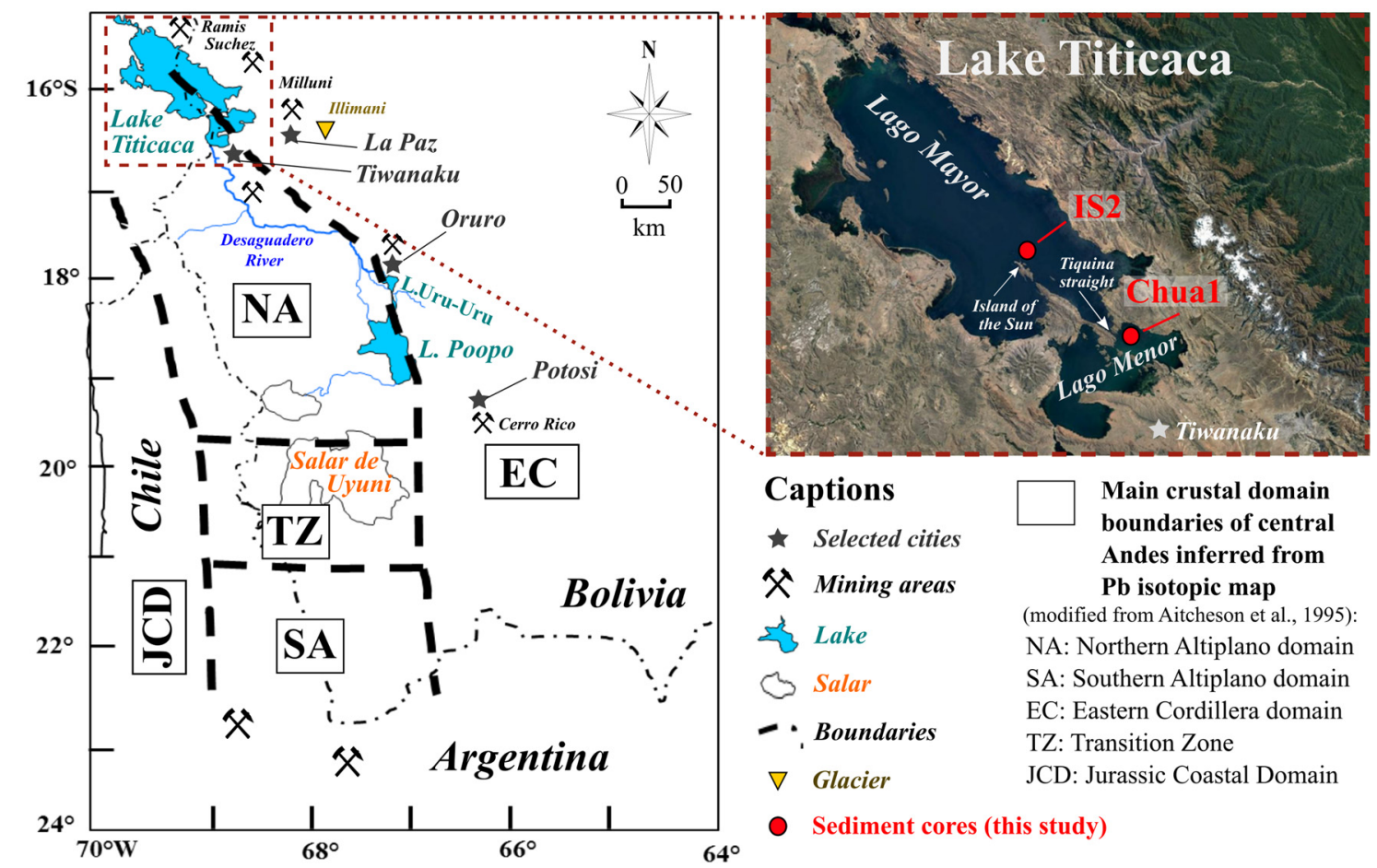

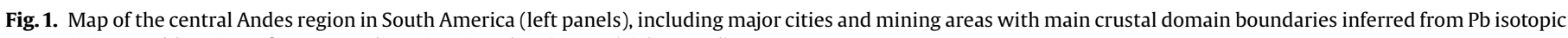
composition; and location of core sampling sites in Lake Titicaca (right panel). 
ornaments), and the state of knowledge of ore extraction and metallurgical techniques.

3 How did metal accumulation differ between wet and dry intervals over the last two millennia?

H3a. Natural dry deposition can be distinguished from anthropogenic deposition of metals by estimating particulate deposition rates during dry periods.

H3b. During dry climate intervals of the last two millennia (identified by biomarkers of lake-level declines), lead isotopic signatures allow the distinction between natural and anthropogenic deposition of metals.

\section{Background information, materials, and methods}

\subsection{The central Andes and Lake Titicaca: environmental settings}

Lake Titicaca (Fig. 1) is located on the Andean Altiplano; a lowrelief, endorheic basin in the central Andes at an average elevation of $3800 \mathrm{~m}$ above sea level (a.s.l.).

It is situated between the volcanic front to the west and the fold-and-thrust belt of the Eastern Cordillera of the Andes. Over much of the central Andes, and especially on the Altiplano, Miocene-Holocene volcanic and sedimentary deposits (mainly andesite-rhyolite composition) overlay the basement rocks (Aitcheson et al., 1995). Previous studies of $\mathrm{Pb}$ isotopes in the central Andes have identified specific geographical provinces with different ore $\mathrm{Pb}$ isotopic compositions summarized in Fig. 1 (Aitcheson et al., 1995; Davidson and de Silva, 1992; Macfarlane et al., 1990; Pichat et al., 2014; Tilton and Barreiro, 1980; Wörner et al., 1992). Both the Southern and Central Altiplano host some of the largest and richest deposits of copper and silver ore in the world, which have been exploited since at least 3 thousand years ago (Lechtman, 2014).

Lake Titicaca consists of two nearly separate basins: the northern basin, named the great lake or "Lago Mayor" (7131 $\mathrm{km}^{2}$; average depth $=100 \mathrm{~m}$; max depth $=285 \mathrm{~m}$ ), and the southern basin, named the small lake or "Lago Menor" (1428 km²; average depth $=9 \mathrm{~m}$; max depth at Chua trough $=41 \mathrm{~m})$. Due to its low latitude $\left(16{ }^{\circ} \mathrm{S}\right)$ and high altitude (3809 $\mathrm{m}$ a.s.l.) location, evaporation accounts for $\sim 90 \%$ of Lake Titicaca's water output (Dejoux, 1992) and has led to substantive lake-level fluctuations in the past (Abbott et al., 1997; Weide et al., 2017). The development of large expanses of totora sedges on the lake's shore, which have been reported to scavenge more than $90 \%$ of terrestrial eroded particles (Dejoux, 1992), prevent the sedimentation of particulate material in shallow water to deeper areas of the lake, making the atmosphere the dominant source of metal pollution in the offshore portions of the system.

\subsection{Sediment core collection}

To reconstruct the mining history in the Lake Titicaca region, two gravity cores were collected during two field campaigns using a UWITEC corer equipped with $90 \mathrm{~mm}$ diameter PVC tubes. The first core, Chua1 (S16 ${ }^{\circ} 12.917 \mathrm{~W}^{\circ} 8^{\circ}$ 46.113, 28 m water depth, length: $161 \mathrm{~cm})$, was retrieved in the deepest trough of the southern basin (Lago Menor) in January 2014. The second one, core IS2 (S15 57.857 W69 ${ }^{\circ} 13.644,19.4 \mathrm{~m}$ water depth, length: 765 $\mathrm{mm}$ ), was collected in the northern basin (Lago Mayor) in June 2014, to the north-east of the Island of the Sun, near the Tiwanaku and Inca offerings site of Khoa reef (Delaere, 2017; Delaere et al., 2019). All details for core splitting and subsampling are given elsewhere (Guédron et al., 2020, 2017). Briefly, the cores were collected for the recovery of a well-preserved sediment-water interface and were subsequently sub-sampled every $0.5-2 \mathrm{~cm}$ until the base of the core for chemical and chronological analyses.

\subsection{Chemical analyses}

To assess the duration, intensity and location of mining activity in the region of Lake Titicaca (Hypothesis 1,2), inorganic tracers and lead isotopes were measured in sediment subsamples after acid digestion. The main extracted metals ( $\mathrm{Cu}$ and $\mathrm{Ag}$ ) and impurities present in local ores ( $\mathrm{Pb}, \mathrm{Hg}, \mathrm{Ni}, \mathrm{Zn}, \mathrm{Sb}$ and $\mathrm{As}$ ) together with lead isotopes were used to fingerprint the local and regional metalworking and smelting sources. In addition, refractory elements ( $\mathrm{Nb}, \mathrm{Rb}, \mathrm{Nd}, \mathrm{Zr}, \mathrm{Ti}, \mathrm{Al}$ ), thought to be unaffected by mining activities, were used to calculate mined-metal enrichment factors. Refractory elements also were used to evaluate the role of climate on metal accumulation and to distinguish natural dry deposition from anthropogenic sources (Hypothesis 3). Sediment volumes of 4 to $8 \mathrm{~cm}^{3}$ were sampled, weighed, freeze-dried, and crushed to obtain a size smaller than $63 \mu \mathrm{m}$ for all chemical analyses. Sediment water content and dry bulk density (DBD) were obtained from the difference in weight prior and post freezedrying. All analytical procedures were conducted using ultra clean techniques (Cossa and Gobeil, 2000) and analyzed in a trace metal clean HEPA filtered laboratory (ISO 7), using high purity acids (Fisher, Optima grade) and ultrapure water (Milli-Q system). Samples were digested with $10 \mathrm{~mL}$ of a mixture of pure acids (HF/ $\left.\mathrm{HCl} / \mathrm{HNO}_{3}, 1: 6: 2\right)$, sonicated for $2 \mathrm{~h}$, and heated on a hot-block (120 ${ }^{\circ} \mathrm{C}, 4 \mathrm{~h}$ ) following a published procedure (Guédron et al., 2006) detailed in Supplementary information (S.I.1).

Major elements ( $\mathrm{Al}, \mathrm{Fe}, \mathrm{K}, \mathrm{Mn}, \mathrm{Mg}, \mathrm{S}$ and Ti) were analyzed with an inductively coupled plasma optical spectrometer (ICP-OES, Varian 720-ES) within the analytical chemistry platform of ISTerre (OSUG-France). Trace elements (Pb, Cu, Ag, Ni, Sb, Zn, As, Cd, Cr, Nb, $\mathrm{Nd}, \mathrm{Rb}$ ) were measured by inductively coupled plasma mass spectrometry (ICP-MS, Perkin Elmer, NexION 300X) using Sc and In as internal standards to correct for instrumental mass bias. The digestion procedure was assessed using certified materials for marine sediments (IAEA 433 and Mess-3). All elements were within the satisfactory target recovery of $100 \pm 15 \%$, except for Cd, which exceeded $130 \%$ (Tables S1 and S2 in SI). The analytical detection limits were well below the measurements of the samples analyzed. More details are presented in S.I.1a (Tables S1 and S2).

Total mercury concentrations ([THg]) were determined by combustion and atomic absorption spectrophotometry (S.I.1) using an AMA 254 analyzer (Altec), following the procedure described in Guédron et al. (2009). Concentrations obtained for repeated analyses of certified reference materials (CRMs) never exceeded the published range of concentrations (IAEA 405: $818 \pm 17 \mathrm{ng} \mathrm{g}^{-1}$ and MESS-3: $91 \pm 9 \mathrm{ng} \mathrm{g}^{-1}$ for $\mathrm{THg}$ - Table S1). Elemental accumulation rates (AR) were obtained from elemental concentration, dry bulk density, and age period covered by each slice.

Lead isotopic analyses $\left({ }^{204} \mathrm{~Pb},{ }^{206} \mathrm{~Pb},{ }^{207} \mathrm{~Pb},{ }^{208} \mathrm{~Pb}\right)$ were performed with a multi-collector inductively coupled plasma mass spectrometer (MC-ICP-MS, Nu Instruments, NuPlasma HR) hyphenated with a desolvator nebulizer (DSN-100, Nu instrument) at a concentration of $20 \mathrm{ppb}$. In order to minimize matrix effects during analysis, $\mathrm{Pb}$ was extracted and purified with an ion exchange resin (Dowex $1 \times 8,100-200$ mesh, Acros Organics) according to a conventional protocol (Barre et al., 2018; Manhes et al., 1978; Monna et al., 1997). Thallium (Tl; NIST 997) was added to all samples to correct the instrumental drift (internal standard). In addition, a standard bracketing method was applied to correct fractionation effects using an isotopic standard of $\mathrm{Pb}$ (NIST 981). Precision obtained for repeated BCR 482 (lichen) was in good 
agreement with certified values (Tables S3b), although the matrix was not sedimentary. The combination of Tl normalization and the classical bracketing method provided an analytical precision of $0.018 \%, 0.016 \%$, and $0.029 \%$ for ${ }^{208} /{ }^{206} \mathrm{~Pb},{ }^{207} /{ }^{206} \mathrm{~Pb}$, and ${ }^{206} /{ }^{204} \mathrm{~Pb}$, respectively. All quality assurance/quality control (QA/QC) are presented in Tables S3a and S3b.

To characterize climate-induced ecological changes in the lake that might affect metal deposition and accumulation and lead isotopic composition (Hypothesis 3), typical organic biomarkers were analyzed. First, organic biomarkers were extracted using pyrolysis-gas chromatography/mass spectrometry (Py-GC/MS) following the method of Tolu et al. (2015). Briefly, the sediment samples were pyrolyzed in a Frontier Labs PY-2020iD oven $\left(450{ }^{\circ} \mathrm{C}\right)$ connected to an Agilent 7890A-5975C GC-MS system. For core Chua1, the sediment samples of units 1,2 , and 3 were analyzed using a sample mass of $5.0 \pm 0.5 \mathrm{mg}, 2.0 \pm 0.2 \mathrm{mg}$ and $500 \pm 50 \mu \mathrm{g}$, respectively. For IS2, a sample mass of $2.0 \pm 0.2 \mathrm{mg}$ was used for the entire set of samples. A data processing pipeline was used under the " $R$ " computational environment to automatically detect and integrate the peaks and extract their corresponding mass spectra. Peak identification was then made using the software "NIST MS Search 2" containing the library "NIST/EPA/NIH 2011" and additional spectra from published studies (Tolu et al., 2015). Individual data processing was done for the IS2 core and for three samples groups of Chua 1 core (i.e., one data processing was done for the lower sediments of unit 1 , one for the upper sediments of unit 1 , and one for the sediments of units 2 and 3 together). The grouping was based on similarity in peaks and baseline between total ion current chromatograms. All QA/QC and results are presented in S.I.1C and table S4. Second, total carbon content (TC, \%), organic carbon content (Corg, \%), and their isotopic composition ( $\delta^{13} \mathrm{C}$ and $\delta^{13} \mathrm{Corg}, \%$ ) in the Chua1 sediment core were measured by Cavity Ring-Down Spectrometer (Picarro, Inc. ${ }^{\circledR}$ ) coupled with a Combustion Module (CM-CRDS, Costech, Inc. ${ }^{\circledR}$ ) using previously reported analytical methods, calibration, and sample preparation (Balslev-Clausen et al., 2013; Guédron et al., 2019; Paul et al., 2007). The precision of the TC/Corg and $\delta^{13} \mathrm{C} /$ $\delta^{13}$ Corg was $0.7 \%$ and $0.2 \%$, respectively for 28 replicates. In core IS2, organic matter $(\mathrm{OM})$ and carbonates $\left(\mathrm{CaCO}_{3}\right)$ were obtained by the loss-on-ignition method (Heiri et al., 2001).

\subsection{Geochronological analyses}

In the uppermost sediment of both cores, short-lived radionuclides were analyzed at $1-\mathrm{cm}$ intervals to $12 \mathrm{~cm}$ depth, using well-type germanium detectors at the Laboratoire Souterrain de Modane (LSM) following the procedure of Reyss et al.(1995). ${ }^{210} \mathrm{~Pb}_{\text {ex }}$ activities were calculated by subtracting the supported ${ }^{226} \mathrm{Ra}$ activities. An age model based on short-lived radionuclides was established with serac R package (Bruel and Sabatier, 2020). Due to the limited vegetation in this high-altitude ecosystem, terrestrial organic macrofossils are scarce in the lake sediment, making biogenic carbonate the best tool for radiocarbon-dating. Hence, AMS dates were obtained from 19 aquatic gastropods (11 from core Chua 1 and 8 from core IS2) by gas ion source accelerator mass spectrometry on biogenic carbonate, at Woods Hole Oceanographic Institution's National Ocean Sciences Accelerator Mass Spectrometry facility, and on 2 microcharcoal samples on the ECHoMICADAS (Environnement, Climat, HOmme - MIcro CArbon DAting System) at the Laboratoire des Sciences du Climat et de l'Environnement (LSCE/IPSL). All dates were calibrated for Southern Hemisphere terrestrial archives using the SHCal13 calibration curve (Hogg et al., 2013), with the Southern Hemisphere postbomb curves from Hua et al. (2013) and a 250-yr reservoir effect for Lago Menor, as used by Abbott et al. (1997)
(Tables S5 and S6). An age model for the whole core was established with clam R package (Blaauw, 2010).

\section{Results and interpretations}

\subsection{Chronology}

For Chua1, our chronological framework was established based on ${ }^{210} \mathrm{~Pb}_{\text {ex }}$ derived sedimentation rate, a ${ }^{137} \mathrm{Cs}$ peak, and 11 radiocarbon dates. A logarithmic plot of ${ }^{210} \mathrm{~Pb}_{\mathrm{ex}}$ activities for Chua1 shows a decreasing linear trend interrupted by an instantaneous deposit between 4 and $6 \mathrm{~cm}$ depth, which yields a mean sedimentation rate of $0.55 \mathrm{~mm}_{\mathrm{yr}} \mathrm{r}^{-1}$, using the CFCS model [Constant Flux Constant Sedimentation (Bruel and Sabatier, 2020)]. The age model derived from ${ }^{210} \mathrm{~Pb}$ is in agreement with the age of the $\mathrm{SH}$ maximum weapons test, identified by the ${ }^{137} \mathrm{Cs}$ peak. The final age-depth model for the entire Chua1 core (Fig. S1) is composed of 3 main units, separated by two hiatuses composed of shell lags, which are dated to between ca. 430 and 1360 BC, and between ca. 2690 and 5340 BC, respectively. The age model is in good agreement with the one previously published by Weide et al. (2017), which was based on 49 radiocarbon measurements. The average resolution for this model is 22 years per $\mathrm{cm}$ for the first 12 $\mathrm{cm}$ and 65 years per $\mathrm{cm}$ for the next $54 \mathrm{~cm}$ (past $4500 \mathrm{yr}$ ). Because the aim of this publication is to generate new insights on the metallurgical period, only the record of the past $\sim 2500$ years is presented. Additional core data are presented in supplementary information (Figs. S3 and S4).

For core IS2, the short-lived radionuclide signal was only measurable within the first $3 \mathrm{~cm}$, likely due to low sedimentation rate in surface sediments. Hence, the oldest resulting age at $3 \mathrm{~cm}$ depth in IS2 was estimated at ca AD 1914 by the CFCS model. The ${ }^{137}$ Cs profile presented very low values and was not used. However, radiocarbon ages followed a consistent stratigraphic trend and enable a consistent age-depth model to be generated between ca. AD 1250 and 1950, with an average resolution of 5 years per $\mathrm{cm}$ (Fig. S2).

\section{2. $\mathrm{Cu}, \mathrm{Ag}, \mathrm{Pb}$ and $\mathrm{Hg}$ enrichment factors and accumulation rates}

\subsubsection{Selection of the conservative crustal element for enrichment factor calculation}

Depth concentration profiles of detrital refractory trace elements, i.e., $\mathrm{Nb}, \mathrm{Nd}, \mathrm{Rb}, \mathrm{Zr}, \mathrm{Al}$, and $\mathrm{Ti}$ (Figs. S3 and S4), show similar variations with depth for the Chua (Chua1) and the Island of the Sun (IS2) cores, indicating a homogeneous source sustained by natural weathering inputs.

In order to discriminate between the natural and anthropogenic origin of $\mathrm{Cu}, \mathrm{Ag}, \mathrm{Pb}$, and $\mathrm{Hg}$, enrichment factors (EFs) were calculated following the conventional equation:

\section{$\mathrm{EF}(\mathrm{X})=([\mathrm{X}] /[\text { refractory }])_{\text {sample }} /([\mathrm{X}] /[\text { refractory }])_{\text {background }}$}

EF corresponds to the ratio of the studied element $(X)$ and a conservative crustal element $(\mathrm{Nd})$ that is not supplied by atmospheric deposition, which are then normalized to the same elemental ratios of a reference material, such as the local geochemical background of the upper continental crust (Eichler et al., 2017; Guédron et al., 2006). Because the two sediment cores were not collected in the same sediment facies and do not cover the same time period, the choice of a common reference for the conservative crustal element was complex. Indeed, the use of the average Upper Continental Crust (UCC) values are not necessarily representative of the regional mineral dust composition, because fractionation processes can occur during weathering, mobilization, and atmospheric transport. For both Chua1 and IS2 cores, the 
average elemental value of the deepest sediment unit of Chua1 core was used, because it corresponds to the Early Holocene (ca. $6000 \mathrm{BC}$ ), when anthropogenic influence is assumed to be negligible. The sediment core based background $[\mathrm{Cu}] /[\mathrm{Nd}],[\mathrm{Pb}] /$ $[\mathrm{Nd}],[\mathrm{Ag}] /[\mathrm{Nd}]$ and $[\mathrm{Hg}] /[\mathrm{Nd}]$ ratios of $0.83,1.07,0.027,0.0012$, respectively, are different from the UCC ratios of $0.96,0.77,0.003$ and 0.0015 , which suggests that the mineral dust composition in the study region is not represented by mean UCC values. The EF calculation was repeated using $\mathrm{Nb}, \mathrm{Rb}, \mathrm{Zr}$, and $\mathrm{Ti}$ as lithogenic elements. The different $\mathrm{Cu}$ EFs are in remarkably good agreement, indicating that the record of the $\mathrm{Cu}$ EFs is not dependent on the lithogenic element chosen (Figs. S5 and S6). The EF of trace metals are plotted against calibrated ages in Figs. 2 and 3 for both Chua 1 and IS2 cores collected in Lake Titicaca. Because the cores were collected in different sub-basins, their background concentrations differ. The highest values are found in Chua, where the deep trough favors sediment focusing, whereas in IS2 elemental concentrations are diluted by the high production of carbonates (Guédron et al., 2020).

\subsubsection{Trends in metal enrichment factors and accumulation rates}

Lead isotope ratios also remain stable at values of $38.87 \pm$ $0.02 \%$ for ${ }^{208} \mathrm{~Pb} /{ }^{204} \mathrm{~Pb}(\mathrm{~N}=11$, Fig. 2), which are similar to those of the Early Holocene background values (EH, $38.86 \pm 0.04 \%$ o, $N=42$, Fig. S9), providing evidence that anthropogenic emissions were minimal before ca. AD 600. The first significant rise in $\mathrm{Cu}$ and $\mathrm{Ag}$ EFs and ARs occurs between AD 900 and 1200, i.e. during the formation of the Tiwanaku state (Fig. 2). In particular, $\mathrm{Cu}$ ARs reach the highest values for the pre-industrial period (considering the entire core) at ca. AD 950. The increase in Pb EF is synchronous with the first ${ }^{208} \mathrm{~Pb} /{ }^{204} \mathrm{~Pb}$ anomaly, characterized by lower ${ }^{208} \mathrm{~Pb} /{ }^{204} \mathrm{~Pb}$ values as compared to the Early Holocene.

In core Chua1, trace metal concentrations and EFs are generally rather stable and low during the Formative Period preceding the
Tiwanaku Period, i.e., before ca. AD 600 (Figs. 2 and S7). During the Late Intermediate Period (LI), also called the Decentralized Polities Period (AD 1150-1450), peaks in Ag, Pb, and Hg EFs and ARs are found in Chua1 (Fig. 2) and IS2 (Fig. 3). The weak resolution of the core Chua1 during this interval only allows the identification of a rise in $\mathrm{Cu}$ EFs and ARs, and to a lesser extent also $\mathrm{Ag}$ and $\mathrm{Pb}$ EFs, at ca. AD 1300.

Consistently, the better-resolved core IS2 (10-20 years per $\mathrm{cm}$ ) shows a distinct increase in $\mathrm{Ag}, \mathrm{Pb}$, and $\mathrm{Hg}$ EFs and ARs at ca. $\mathrm{AD}$ 1300 , followed by at least two peaks, which last less than 50 years, coincident with ${ }^{208} \mathrm{~Pb} /{ }^{204} \mathrm{~Pb}$ anomalies to less radiogenic values (i.e., pink circles in Fig. 3). At the end of the Late Intermediate Period, a sharp increase in Cu EF and AR is found in core IS2 at ca. AD 1400 (Fig. 3), which is not synchronous with any $\mathrm{Ag}, \mathrm{Pb}$, or $\mathrm{Hg}$ EFs peaks, nor with any $\mathrm{Pb}$ isotope anomaly.

The major increase in the EFs and ARs of all metals is found during the Inca Empire, and Colonial Period. Such increases are found synchronously in both cores, with a first inflection during the Inca Empire, followed by large and long-lasting peaks that reach their optima during the 18th century, followed by a progressive decline around AD 1830. These patterns (Figs. 2,3, S7, and S8) are consistent with other records (sediment and ice cores) of $\mathrm{Ag}, \mathrm{As}, \mathrm{Cu}, \mathrm{Pb}, \mathrm{Hg}$, and Sb from the central Andes (Abbott and Wolfe, 2003; Cooke, 2006; Cooke et al., 2008b, 2011; Cooke et al., 2013; Guédron et al., 2019; Uglietti et al., 2015). Surprisingly, Cu EFs and ARs greatly decline in core IS2, whereas they follow the same trends as other metals in core Chua1. Only Hg shows a slightly different pattern, with a decline starting at the end of the 16th century, preceding a decline in the other metals by at least one century.

\subsection{Dust deposition periods and $\mathrm{Pb}$ isotopes}

The $\mathrm{Pb}$ isotopic signatures combine two atmospheric $\mathrm{Pb}$ sources, i.e. emissions of mineral dust and of mining or

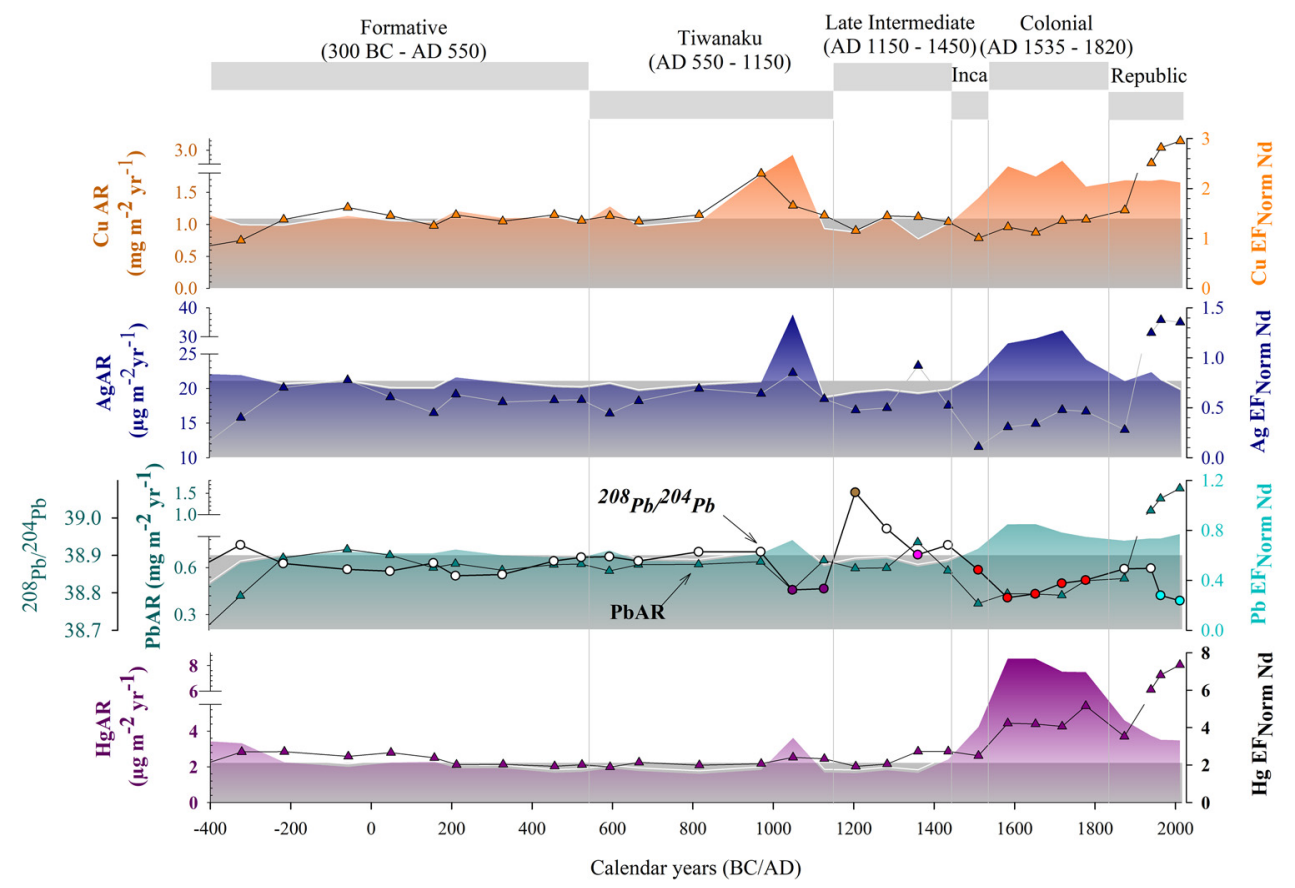

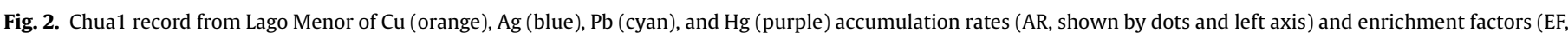

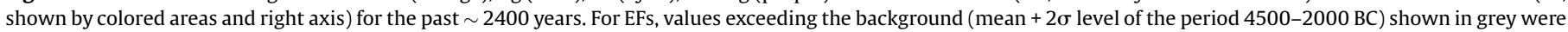

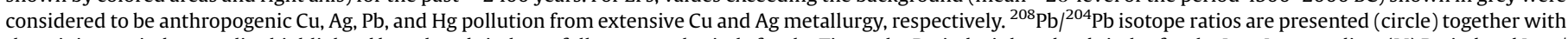

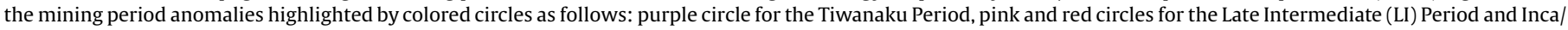

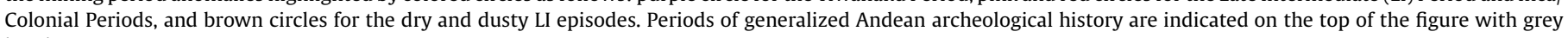
bands. 


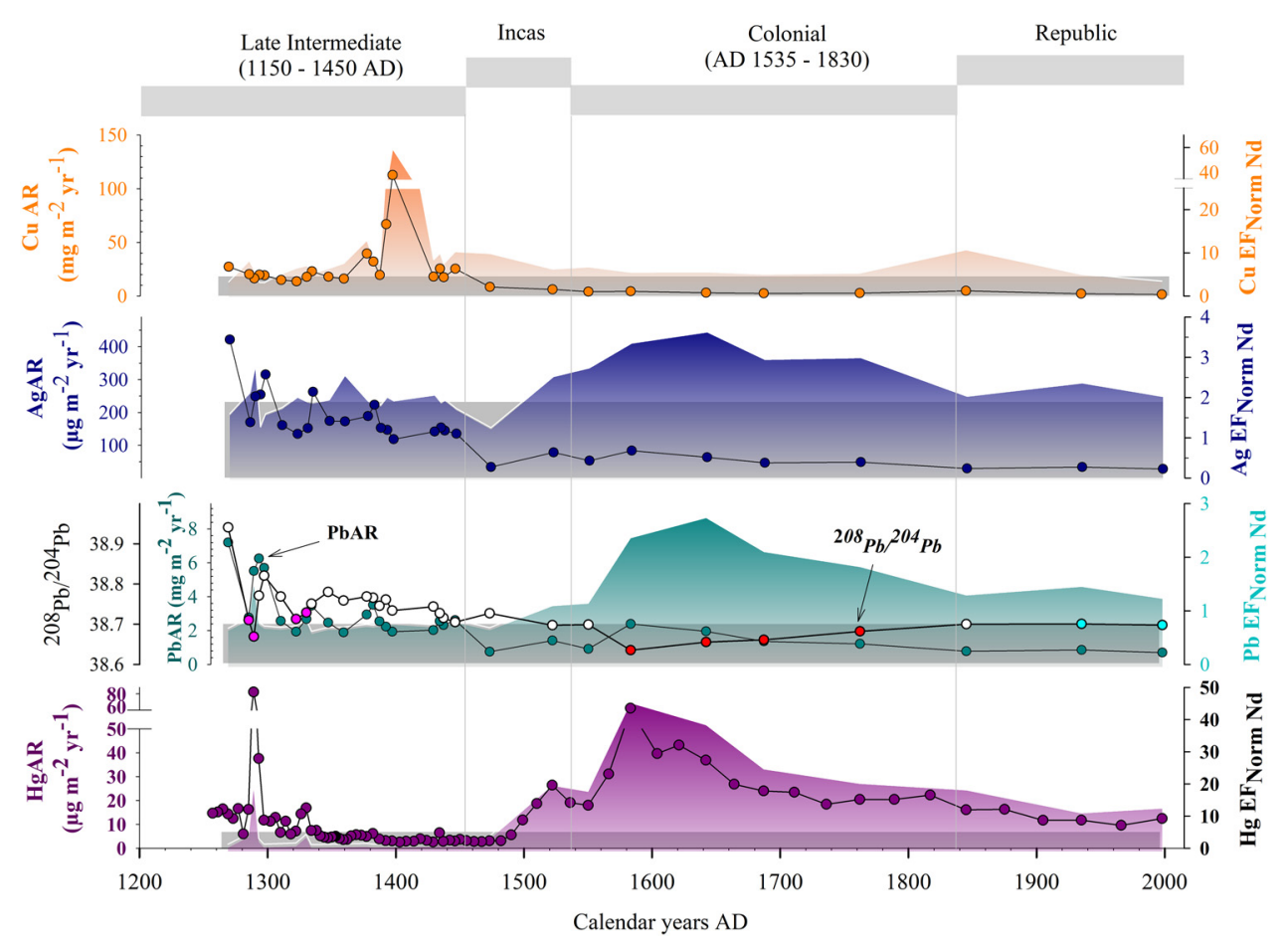

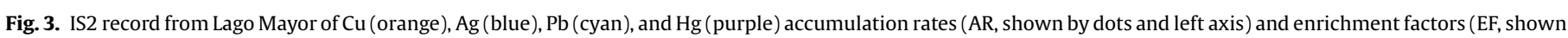

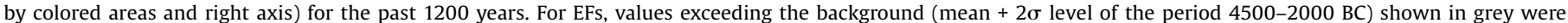

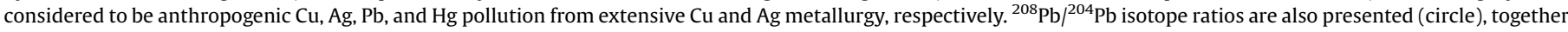

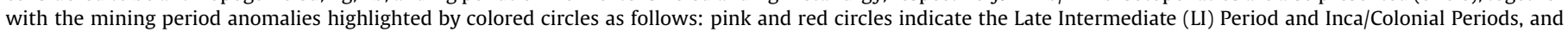
brown circles indicate the dry and dusty LI episodes. Periods of generalized Andean archeological history are indicated on the top of the figure with grey bands.

metallurgical processing, which are important to disentangle for interpreting the anthropogenic signal. To account for the mineral dust deposition in the records of anthropogenic $\mathrm{Pb}, \mathrm{Nd}$ ARs were used as a proxy of dust deposition (Fig. 4). To complement this proxy, dry periods also were identified via the reconstruction of decreases in Lake Titicaca water levels, which coincide with high mineral dust deposition in ice cores collected in the region of Lake Titicaca (Eichler et al., 2017, 2016; Thompson et al., 1998, 1985). To do so, four different and independently determined proxies were used: calcium carbonate $\mathrm{ARs}\left(\mathrm{CaCO}_{3} \mathrm{ARs}\right), \delta^{13} \mathrm{C}_{\text {org }}$, abundances of $n$-alkanes with an odd number of carbon (C) from 25 to 31 (noted hereafter as $n$-alkanes $\mathrm{C}_{25-31}$ ), and abundance of chlorophyll (Fig. 4). Increases in $\mathrm{CaCO}_{3} \mathrm{AR}$ were used as a proxy of dry periods, with higher chemical precipitation of $\mathrm{CaCO}_{3}$ (with increasing salinity due to evaporation) as well as higher production of Characeae (favored in saline conditions) in the photic zones of Lake Titicaca (Apolinarskaa et al., 2011; Baker et al., 2001; Dejoux, 1992; Guédron et al., 2017). Characeae is a macroscopic green algal genus, whose photosynthetic activity results in encrustations of $\mathrm{CaCO}_{3}$, such that its dry mass is often up to $\sim 70 \% \mathrm{CaCO}_{3} . \delta^{13} \mathrm{C}_{\text {org }}$ was used to track changes in the source of organic matter $(\mathrm{OM})$ to the sediment, with higher values attributed to Characeae $(-10 \pm 6 \%$ ) and lower values to plankton $(-20 \pm 5 \%$ ) OM (Cross et al., 2000; Guédron et al., 2020). Finally, the sum of $n$-alkanes $C_{25-31}$ was used as a proxy for fresh and deep-water algae, such as the green algae Botryococcus braunii (Metzger et al., 1989; Theissen et al., 2005). Although long-chain $n$-alkanes are a commonly used proxy for terrestrial organic inputs, green and brown algae also contain these compounds and represent their main sources in Lake Titicaca sediments due to extremely low inputs of terrestrial organic matter; as is evident from the analysis of macro and micro-remains and the absence of lignin (SI.7 and SI.8). In addition, long-chain $n$ alkanes are of low abundances in Characeae (Holtvoeth et al., 2016). Finally, chlorophyll was used as a proxy for algal productivity (Rydberg et al., 2020), which could reflect increased productivity for both freshwater algae and Characeae.

The sediments from the Middle Holocene dry period (Chua1 core; Fig.4A) have the highest peak of $\mathrm{Nd} \mathrm{AR}$, and they are characterized by the highest $\mathrm{CaCO}_{3}$ ARs, the lowest abundances in $n$-alkanes $\mathrm{C}_{25-31}$ (i.e., lower proportions of freshwater algal inputs), and the most positive $\delta^{13} \mathrm{C}_{\mathrm{org}}$ values (i.e., $-15.6 \pm 3.3 \%$ ) indicative of organic inputs from macrophytes. The inspection of the macro- and micro-remains in the core sediments confirms the importance of the carbonate fraction, noticeably dominated by Characeae encrusted thalli and seeds (e.g. photograph of the sample 52 in Fig. S.11). Together, these proxies clearly demonstrate that Lake Titicaca was shallower during the Middle Holocene and was subject to dust deposition events. Interestingly, chlorophyll is at its highest abundance during the Middle Holocene, probably because of stronger productivity by Characeae mats when Lake Titicaca was shallow than by freshwater algae when the level of Lake Titicaca was high. During the Late Holocene (100 BC to Present), the $\mathrm{CaCO}_{3}$ ARs are 4-10 times lower than during the Middle Holocene, the abundances of $n$-alkane $C_{25-31}$ are $\sim 2-3$ times higher, and $\delta^{13} C_{\text {org }}$ values are typical for phytoplankton (i.e., $-20.0 \pm 0.7 \%$ ), demonstrating a return to higher lake- levels, lower Characeae productivity (only on lake shores), and a dominance of phytoplankton organic matter. Those results are supported by inspection of macro- and micro-remains, which reveal the near disappearance of Characeae macrophytes and a prevalence of green planktonic microalga of Botryococcus braunii and Pediastrum boryanum (Fig. S11). In core IS2, which covers AD 1300 to Present, $\mathrm{CaCO}_{3}$ ARs are higher by more than one order of magnitude than in the Chua1 Middle Holocene sediments, nalkanes $\mathrm{C}_{25-31}$ abundances are 2-3 times lower, and chlorophyll abundances are similar. Although these results demonstrate the great difference between the organic-rich sediments of Chua1 and the carbonate-rich sediments of IS2 (Guédron et al., 2020), the 


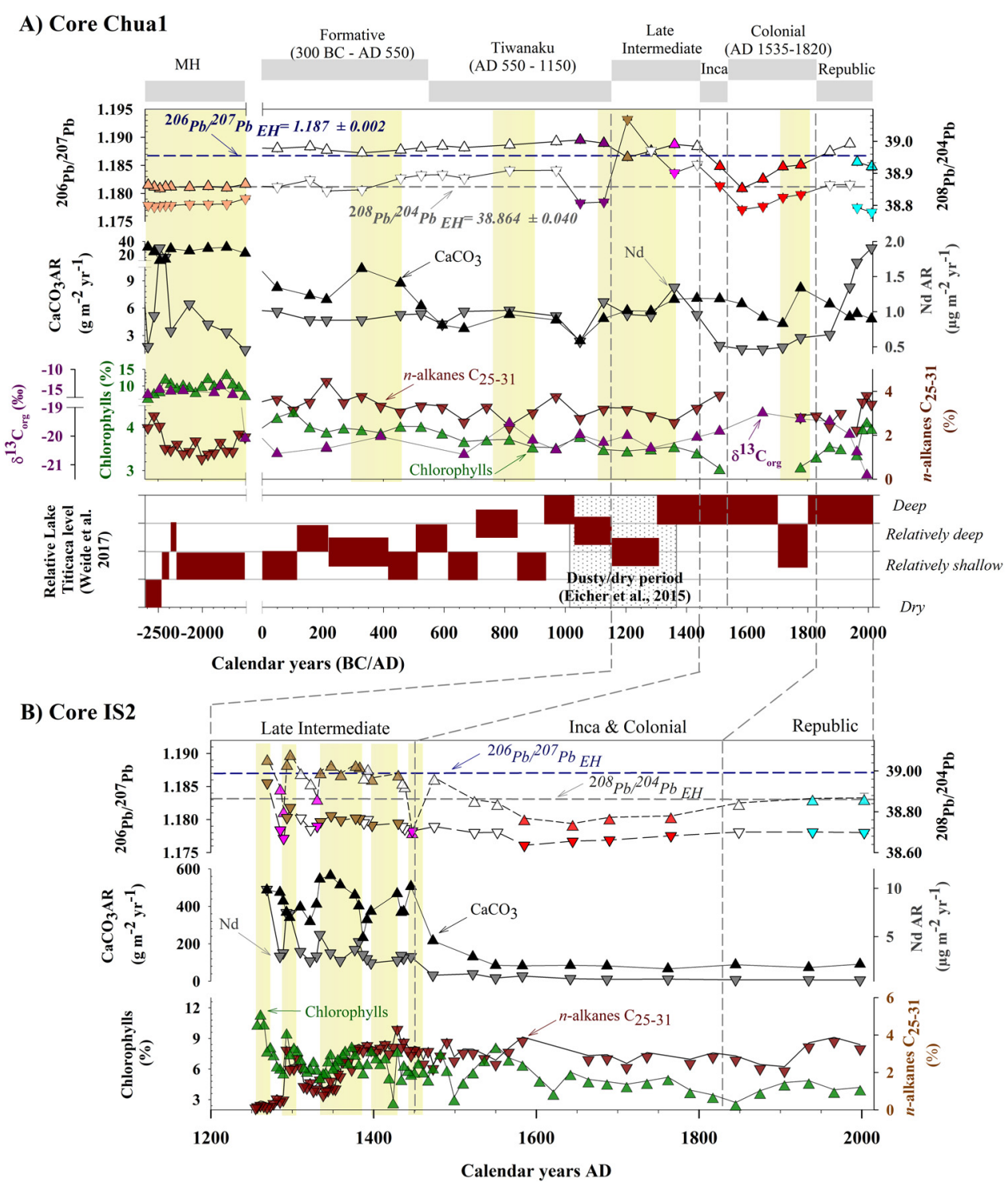

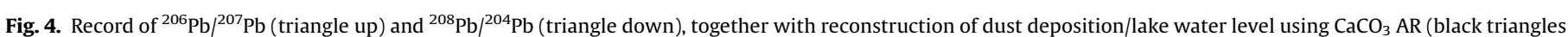

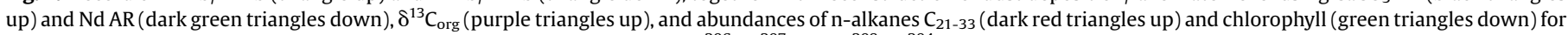

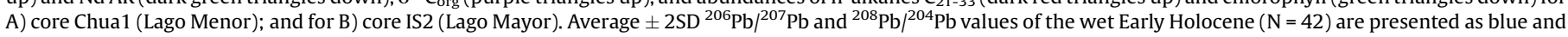

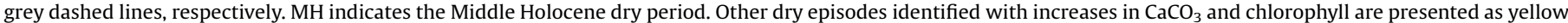

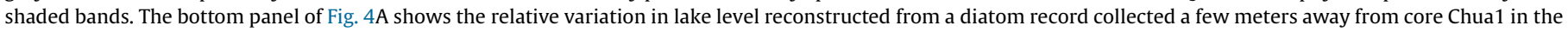
Chua trough (Weide et al., 2017) and the dusty dry period recorded in a Illimani Ice core (Eichler et al., 2015).

decrease in Lake Titicaca water level results in higher carbonate input to sediments at both sites.

On the whole, negative shifts in $\mathrm{CaCO}_{3} \mathrm{AR}$ synchronous with positive shifts in Nd AR and $n$-alkanes $C_{25-31}$ in core Chua 1 indicate three long-lasting dry events of lower intensity and duration than the Middle Holocene: two during the Formative Period (AD 250500 ), one during the second half of the Tiwanaku Period (AD 800950 ), and one during the Late Intermediate Period (AD 1100-1400). In core IS2 (which covers the Late Intermediate Period at higher resolution), four dry events of short duration ( $\sim 20-40$ years) were identified between ca. AD 1250 and 1420 (Fig. 4B).

This reconstruction of dry periods and events is in very good agreement with previous reconstructions (Abbott et al., 1997; Guédron et al., 2018; Weide et al., 2017), enabling an evaluation of the effect of dust deposition on the $\mathrm{Pb}$ isotopic composition.

During the Middle Holocene dry period (light orange symbols; Fig. 4), both ${ }^{206} \mathrm{~Pb} /{ }^{207} \mathrm{~Pb}(1.182 \pm 0.001)$ and ${ }^{208} \mathrm{~Pb} /{ }^{204} \mathrm{~Pb}(38.805 \pm$ $0.008)$ ratios $(\mathrm{N}=10)$ are much lower than during the wet Early
Holocene period (before ca. BC 2500), a period when the average values are $1.187 \pm 0.002\left({ }^{206} \mathrm{~Pb} /{ }^{207} \mathrm{~Pb}\right)$ and $38.864 \pm 0.040$ $\left({ }^{208} \mathrm{~Pb} /{ }^{204} \mathrm{~Pb}, \mathrm{~N}=42\right.$, Fig. $\left.4 \mathrm{~A}\right)$. Hence, if the source of dust did not change over time, lower $\mathrm{Pb}$ isotope ratio values would be expected for dry events over the entire Holocene.

During the Late Holocene, only very small shifts to lower values for both $\mathrm{Pb}$ isotope ratios occurred during the two dry events of the Formative Period, and no shift was observed for the dry event of the second half of the Tiwanaku Period. The only important changes were found for ${ }^{208} \mathrm{~Pb} /{ }^{204} \mathrm{~Pb}$, which increases during the dry event(s) of the late Intermediate Period in both Chua1 and IS2 cores (i.e., AD 1200-1400, brown symbols in Fig. 4). These results demonstrate that dust deposition did not significantly affect the $\mathrm{Pb}$ isotopic record of the Late Holocene in the Chua1 core, except for the Late Intermediate Period, previously shown to be an interval of enhanced dust deposition (Eichler et al., 2016). Our results from the IS2 core further show that ${ }^{208} \mathrm{~Pb} /{ }^{204} \mathrm{~Pb}$ isotope ratios of the Late Intermediate dry events shift to more radiogenic values than those 
of the dry Middle Holocene and the wet Early Holocene periods, which suggests a different source of dust for the lake during these events than during the Middle Holocene.

\subsection{Fingerprinting of ore extraction sources with $\mathrm{Pb}$ isotopes}

For both Chua1 and IS2 cores, the $\mathrm{Pb}$ isotope ratio data from the pre-mining epoch (i.e., Early Holocene, Middle Holocene, and Formative Period) plot along a linear trend within the values of the Province IIIa [i.e., Paleozoic sedimentary rocks, Fig. 5A (Macfarlane and Lechtman, 2014)]. The pre-mining $\mathrm{Pb}$ isotope ratios also plot within the values of the Eastern Cordillera domain (EC; Fig. 5B), which has the most radiogenic $\mathrm{Pb}$ pool [i.e., higher values of $\mathrm{Pb}$ isotope ratios: ${ }^{206} \mathrm{~Pb} /{ }^{204} \mathrm{~Pb}>18.6,{ }^{207} \mathrm{~Pb} /{ }^{204} \mathrm{~Pb}<15.64$, and ${ }^{208} \mathrm{~Pb} /{ }^{204} \mathrm{~Pb}<38.9$; Aitcheson et al. (1995)]. Although Chua1 and IS2 $\mathrm{Pb}$ isotope ratios follow the same trend, lower values are found for the Lago Mayor (IS2) compared to the Lago Menor (Chua1) core, indicating less-radiogenic $\mathrm{Pb}$ sources in the northern part of the catchment (Lago Mayor) compared to the southern (Lago Menor) part of the Eastern Cordillera.

When both the pre-mining and mining epochs are considered, the $\mathrm{Pb}$ isotope data still follow the same linear trend, but the data of the mining epochs extend from the Eastern Cordillera to the Northern Altiplano domain (EC and NA, Fig. 5B), illustrating that the $\mathrm{Pb}$ deposited during the mining epochs is composed of significant $\mathrm{Pb}$ sources from both the northern and southern Altiplano region. Three different $\mathrm{Pb}$ isotope anomalies from the linear trend can be identified, i.e. during (i) the Tiwanaku Period, (ii) the Late Intermediate Period and (iii) the Inca Empire and Colonial period.

The Tiwanaku mining $\mathrm{Pb}$ isotope anomalies (purple triangles; Fig. 5) have the most radiogenic ${ }^{208} \mathrm{~Pb} /{ }^{204} \mathrm{~Pb}$ and ${ }^{206} \mathrm{~Pb} /{ }^{204} \mathrm{~Pb}$ values, which fit into the Eastern Cordillera domain, and ${ }^{207} \mathrm{~Pb} /{ }^{204} \mathrm{~Pb}$ ratios that are amongst the lowest values. These values are similar to those of the host rock of the $\mathrm{Cu}$ mines from the vicinity of Tiwanaku, which are within the Western Cordillera domain [Figs. 5B and C (Aitcheson et al., 1995; Macfarlane and Lechtman, 2014)]. Although only two samples are available for this interval, our data support previous archeological findings based on $\mathrm{Pb}$ isotopic composition of bronze artifacts (Fig. 5C), which attributed the source of $\mathrm{Cu}$ ores used by the Tiwanaku civilization as close to its capital city (Macfarlane and Lechtman, 2014).

The Late Intermediate $\mathrm{Pb}$ isotope ratio anomalies (pink symbols; Fig. 5) are in phase with peaks of $\mathrm{Pb}, \mathrm{Ag}$, and $\mathrm{Hg}$ EFs (Figs. 2, 3 and 4) and show large variations towards less-radiogenic $\mathrm{Pb}$ values (Fig. 5B).

The Late Intermediate $\mathrm{Pb}$ isotope ratio data fit into the Northern Altiplano domain, which includes the isotopic signature of mines $(\mathrm{Pb}, \mathrm{Ag}$, and $\mathrm{Sn})$ of the Southern Altiplano [e.g., Cerro Rico and Porco (Miller et al., 2002, 2007)]. These results support prior conclusions of intense pre-Inca mining in the Potosi region (Abbott and Wolfe, 2003; Cooke et al., 2008a), but local mining in the Lake Titicaca region cannot be excluded (Lechtman, 2014; Schultze et al., 2016, 2009). Furthermore, this period corresponds to a dry episode (section 3.3) characterized by elevated dust deposition for which a more radiogenic $\mathrm{Pb}$ signature typical of the Eastern Cordillera domain was observed in core IS2 (yellow bands and brown symbols; Figs. 4 and 5). The absence of anthropogenic $\mathrm{Pb}$ signatures (recorded with less-radiogenic $\mathrm{Pb}$ ) during these dry events suggests that mining activities occurred mainly during wetter periods or that natural mineral dust deposition during dry intervals masked the mining and metallurgical processing imprint.

Finally, the largest and long-lasting $\mathrm{Pb}$ anomalies are found during the Inca Empire and Colonial Period with, as for the Late Intermediate Period, a shift towards less-radiogenic isotope values typical of the NA domain values, which confirms that the Potosi region was a major mining area. Our ${ }^{206 / 207} \mathrm{~Pb}$ and ${ }^{208 / 206} \mathrm{~Pb}$ ratios also are consistent with available data reported for the Potosi Ag mining region [i.e., cero Rico ores, Porco mine tailings, and Rico Pilcomayo sediment - Fig. 5C (Miller et al., 2007)].
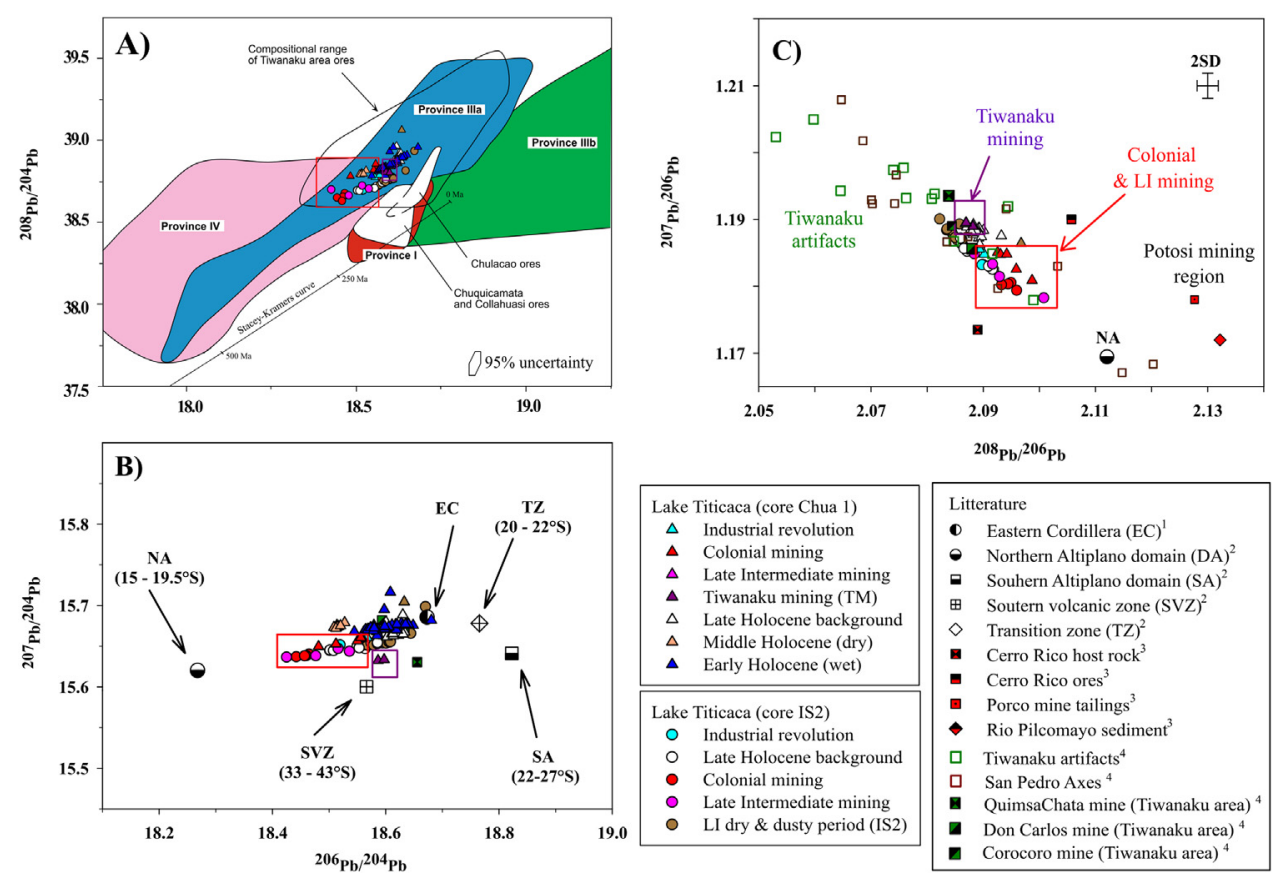

\begin{tabular}{|c|c|}
\hline Lake Titicaca (core Chua 1) & Litterature \\
\hline$\Delta \quad$ Industrial revolution & - Eastern Cordillera $(E C)^{1}$ \\
\hline$\Delta \quad$ Colonial mining & - Northern Altiplano domain (DA $)^{2}$ \\
\hline$\Delta \quad$ Late Intermediate mining & - Souhern Altiplano domain $(\mathrm{SA})^{2}$ \\
\hline$\Delta$ Tiwanaku mining (TM) & 田 Soutern volcanic zone (SVZ) \\
\hline$\Delta \quad$ Late Holocene background & $\diamond \quad$ Transition zone $(\mathrm{TZ})^{2}$ \\
\hline $\begin{array}{ll}\Delta & \text { Middle Holocene (dry) } \\
\Delta & \text { Early Holocene (wet) }\end{array}$ & - Cerro Rico host rock ${ }^{3}$ \\
\hline A Early Holocene (wet) & - Cerro Rico ores ${ }^{3}$ \\
\hline Lake Titicaca & Porco mine tailings ${ }^{3}$ \\
\hline$\circ$ Industrial revolution & - Rio Pilcomayo sediment ${ }^{3}$ \\
\hline O Late Holocene background & ․ Tiwanaku artifacts ${ }^{4}$ \\
\hline - Colonial mining & ( San Pedro Axes ${ }^{4}$ \\
\hline - Late Intermediate mining & a QuimsaChata mine (Tiwanaku area) ${ }^{4}$ \\
\hline - LI dry \& dusty period (IS2) & D Don Carlos mine (Tiwanaku area) ${ }^{4}$ \\
\hline
\end{tabular}

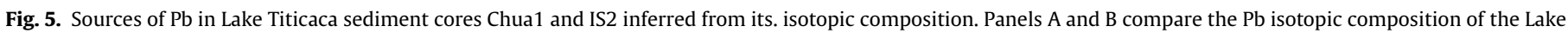

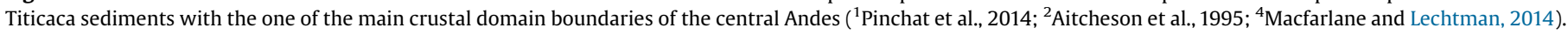

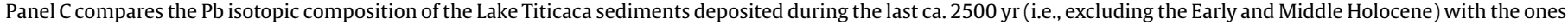

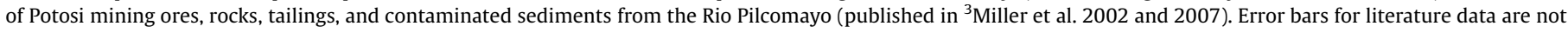
presented. 


\section{Discussion}

\subsection{Pre-mining: the formative period ( $400 \mathrm{BC}$ to $550 \mathrm{AD}$ )}

In the Lago Menor (Chua1 core), no evidence was found for early $\mathrm{Cu}$ pollution ( $\sim 700$ to $50 \mathrm{BC}$ ), as was recorded in an ice core from Illimani glacier and attributed to the Andean Chiripa and Chavin cultures (Eichler et al., 2017). Nor was evidence found for early Ag mining (between $40 \mathrm{BC}$ and $\mathrm{AD} 120$ ) on the northern shores of Lake Titicaca (Schultze et al., 2016, 2009). The Chiripa Culture in particular, which developed in the southern side of Lake Titicaca, is known to have made significant innovations in metal, ceramic, and lithic technologies (Janusek, 2008). The volume of metal transformation was assuredly an order of magnitude lower than during the latter periods (Janusek, 2008), likely explaining the absence of evidence in the Chua 1 sediment record. Lead isotope ratios have similar values in the Formative Period to those of the pre-anthropogenic geogenic baseline values, suggesting that early mining activities were too distant or of too small a magnitude to be recorded in the southern Lake Titicaca basin at that time. The relatively weak resolution of the Chua1 record in this interval also would likely mask shortduration mining episodes.

\subsection{Copper mining: the Tiwanaku period ( $A D$ 550-1150)}

During the Middle Horizon (AD 550-1150), the significant rise in $\mathrm{Cu}, \mathrm{Ag}, \mathrm{Pb}$, and $\mathrm{Hg}$ EFs between $\mathrm{AD} 900$ and 1200 confirms the occurrence of important $\mathrm{Cu}$ mining activities during the Tiwanaku Period, as reported in the Illimani ice record (Eichler et al., 2017). In particular both $\mathrm{Cu}$ EFs and ARs reach their highest values for the pre-industrial epoch during the expansion phase of the Tiwanaku state (Bandy, 2013; Bandy et al., 2013), known as Tiwanaku V phase (AD 750/850-1100). The synchronous rise of Sb, Zn, Ni, and As EFs (Fig. S4) at that time is consistent with extensive use of ternary $\mathrm{Cu}-$ As-Ni alloys for the production of architectural cramps used in monumental constructions of the capital, as well as for the fabrication of tools and ornamental objects with a similar composition as the alloys used in northwest Argentina (Couture and Sampeck, 2003; Lechtman, 2003). Archeological studies have reported an active exchange network of llama caravans that carried goods, perhaps metallic ores, from northwest Argentina to the city of Tiwanaku (Lecoq, 1987; Nielsen, 1998; Núñez, 1987). However, the $\mathrm{Pb}$ isotopic study of a large set of bronze artifacts from both San Pedro de Atacama and Tiwanaku by Macfarlane and Lechtman (2014) did not show evidence of a Pb signature from the southcentral Andean zone. The peculiar $\mathrm{Pb}$ isotope values found in the Chua1 core are in accordance with their findings, supporting that the majority of the Tiwanaku ternary bronze artifacts were made from ores obtained not far from Tiwanaku itself. However, because the $\mathrm{Pb}$ isotopes exhibit much less variation from south to north than from west to east, one cannot exclude a mixing of $\mathrm{Pb}$ isotopic signatures of Tiwanaku ores with those from mining areas located in the south (e.g., Pulacayo in the Sur Lipez region), which were exploited during this epoch and have $\mathrm{Pb}$ isotopic signatures close to those of the Tiwanaku area (Cruz, 2009; Macfarlane and Lechtman, 2014). Furthermore, the large $\mathrm{Cu}$ signal found in our records could also result from the re-smelting of the metals in the capital city of Tiahuanaco, in agreement with archeologists who described the capital Tiwanaku city as a locus of innovation and experimentation in metalworking throughout its lifespan (Lechtman, 2003). Finally, the weak $\mathrm{Hg}$ peak during this epoch, as compared to the following mining epochs, suggests that such $\mathrm{Cu}-$ centered mining activities did not result in intense and regional $\mathrm{Hg}$ pollution, in agreement with the low $\mathrm{Hg}$ content of $\mathrm{Cu}$ ores with respect to $\mathrm{Ag}$ ores in the Andes (Cooke et al., 2011).

\subsection{Late Intermediate period ( $A D$ 1150-1450)}

After the disintegration of the Tiwanaku state, the peaks in $\mathrm{Ag}, \mathrm{Pb}$, and $\mathrm{Hg}$ EFs and ARs during the 13th and 14th centuries found in the IS2 core testify to the continuity of metallurgy in an intense but discontinuous manner, characterized by peaks of metal deposition, each with a duration on the order of twenty years (Fig. 3). The Late Intermediate Period, also called the Decentralized Policies Epoch or Altiplano Period, is known as a change in the political landscape of the Tiwanaku state. Fortified settlements were reported to fracture this landscape spatially and socially and allowed for increasing endemic warfare after AD 1300 (Arkush., 2011; Covey, 2012), followed by Inca conquest ca. AD 1450 (Covey, 2012). The production of bronze (mostly tin bronze) likely accelerated in the Lake Titicaca basin (Lechtman, 2003), but intense Ag mining was also reported in the south-central Altiplano [i.e., Sur Lipez and Potosi region (Abbott and Wolfe, 2003; Cooke et al., 2011; Cruz, 2009)], which is considered as the most developed region economically posterior to the Tiwanaku Period (Cruz and Joinville Vacher, 2008). Our Pb isotope data support a dominant supply of $\mathrm{Pb}$ from this latter region (i.e., Oruro and Potosi), although significant quantities of dust likely originating from the Eastern Cordillera region probably diluted this mining signal during this dry period (Fig. 4). Hence, both the larger polymetallic pollution (i.e., $\mathrm{Ag}, \mathrm{Hg}, \mathrm{Pb}$ ) and $\mathrm{Pb}$ isotope signatures from our Lake Titicaca records support a change or diversification of mined ores from local to regional point source mining activities.

\subsection{Inca and Colonial Ag mining period ( $A D$ 1450-1830)}

The most intense mining period lasts from the Inca Empire to the end of the Colonial Period, with increases in all metal EFs, with ARs for most of them exceeding those of the Industrial Revolution (Figs. 3 and 4). Such a large and long-lasting mining signal is consistent with numerous metal records from environmental archives collected throughout the central Andes (Abbott and Wolfe, 2003; Cooke, 2006; Cooke et al., 2008b, 2011; Cooke et al., 2013; Guédron et al., 2019; Uglietti et al., 2015). In both parts of the lake, our reconstructions of metal EFs and ARs show a first inflection of metal deposition after the arrival of the Inca (i.e., ca. AD 1400/1430) in the Lake Titicaca region, followed by a second one beginning after the arrival of the Spaniards (AD 1532). Metal EFs and ARs reach their maximum during the 17th century and then progressively decline until the war of independence at ca. AD 1830. Although many regions of the Andes were mined by both the Inca and the Spaniards at that time, our $\mathrm{Pb}$ isotope fingerprinting supports that the main source of $\mathrm{Pb}$ to the sediment record of Lake Titicaca originates from the Potosi region, consistent with other $\mathrm{Pb}$ AR and isotopic records from the south-central Andes (Abbott and Wolfe, 2003; Cooke et al., 2008a; Uglietti et al., 2015). This is also in accordance with historical and archeological data that have indicated the Porco-Potosi mining region as the epicenter of mining during both the Inca and Colonial Periods (Cohen, 2008). Only $\mathrm{Hg}$ shows a slightly different pattern, with a decline starting from the end of the 16th century, i.e. at least one century earlier than other metals. Such a pattern is consistent with other Andean Hg records (Cooke et al., 2009a, 2011, 2013; Guédron et al., 2019) and is attributed to improvements in the extraction of $\mathrm{Ag}$ by $\mathrm{Hg}$ amalgamation, which lowered elemental $\mathrm{Hg}$ losses during refining (compared to smelting) through the formation of calomel, and to the improvement in the recycling of $\mathrm{Hg}$ during the heating stage of the amalgam (Guerrero, 2012, 2016).

\subsection{Andean mining in a global context}

Before the arrival of the Spaniards, mining activities in the Andes developed and rose in isolation from that on other 
continents. Because of the absence of intercontinental socioeconomic exchanges, none of the major metallurgic Ages in Eurasia, e.g., the Roman Empire and the Medieval Periods (Hong et al., 1994; Longman et al., 2018; Thevenon et al., 2011), are synchronous with those of the Americas. In addition, the richness of Andean metal deposits (Sillitoe, 2003) and the non-monetization of precious metals also explains why most of the metallurgy in South America was only centered on the development of sophisticated copper alloys, silver, and gold metallurgy for architectural and ornamental needs. In contrast, European metallurgy rapidly focused on Iron metallurgy (from at least the first millennium $\mathrm{BC}$ ), because of very limited resources in $\mathrm{Cu}, \mathrm{Ag}$, and $\mathrm{Au}$ and important social, economic, and technological exchanges within Eurasia (Collis, 2003). In the context of paleoenvironmental records, the limited interhemispheric mixing (Slemr et al., 1981) and short residence time of trace metals in the atmosphere (Elbaz-Poulichet et al., 2020) precluded any evidence of the mining signal from Andean regions in sites of the Northern Hemisphere (Engstrom et al., 2014; Osterberg et al., 2008).

At the onset of the Colonial Period, both mining activities and trading connected South America to Eurasia and shifted the focus of extractive activities towards Ag and Au. At that time, the mining signal (i.e., mercury) in environmental records became synchronous in the two hemispheres, as most of the mercury extracted for the amalgamation of South American silver mines (e.g., Potosi) was extracted in the Spanish mines (i.e., Almaden) until the discovery of the Huancavelica mercury mine in Peru (Guerrero, 2012; Nriagu, 1994). Finally, the globalization of metal pollution occurred during the industrial revolution through the global rise of atmospheric concentrations in metals, which homogenized the record of metal contamination at the global scale (Nriagu, 1996).

\section{Conclusion}

The analysis of the $\mathrm{Pb}$ isotopes recorded in the Lake Titicaca sediments allowed distinguishing amongst the ore bodies that have been exploited by ancient Andean civilizations. Moreover, the coupled study of metal accumulation histories has provided an added value, allowing qualifying and quantifying the evolution of the mining activities intensity over time. Hence, our study provides answers to the following research questions raised in the Introduction:

(1) The accumulation of a range of ore-derived metals in the two Lake Titicaca cores allowed an assessment of the intensity and duration of each mining period in the central Altiplano region. The first evidence for metallurgy was found during the late Tiwanaku Period (AD 900-1150) and was primarily associated with the exploitation of $\mathrm{Cu}$ ores. During the Late Intermediate Period (AD 1150-1450), mining activities were more intense but discontinuous, and attributed to both $\mathrm{Cu}$ and $\mathrm{Ag}$ mining. The most intense and continuous mining activities were recorded during the Inca and Colonial Periods (AD 1450-1830) and were mainly attributed to $\mathrm{Ag}$ mining.

(2) The comparison of our sediment $\mathrm{Pb}$ isotopic signature with those of archeological artifacts and regional ores provides consistent results supporting that Tiwanaku $\mathrm{Cu}$ mining was centered in the area of Lake Titicaca, whereas during the Late Intermediate to the Colonial Periods, mining activities were mostly performed in the south-central Altiplano (i.e., the southern Potosi region). During the expansion phase of the Tiwanaku state, most of the metallurgy was devoted to ternary $\mathrm{Cu}-\mathrm{As}-\mathrm{Ni}$ alloys for monumental constructions of the capital. In the following Late Intermediate Period, the regional production of bronze changed to mostly tin bronze in parallel to the diversification of mined ores, and the development of mining in the south-central Altiplano. Mining became more extensive, continuous, and mainly centered in the Potosi region, as metallurgy was more elaborated, and power became centralized during the Inca and subsequent Colonial Periods.

(3) Significant climate change during the Late Holocene, including a relatively long dry episode during the Late Intermediate Period, resulted in dust depositions that did not significantly affect the $\mathrm{Pb}$ isotopic record, and allowed the differentiation of mining activities vs natural dry metal deposition during these periods.

Although a major rise in $\mathrm{Cu}$ deposition together with typical $\mathrm{Pb}$ isotopic ratio anomalies were identified, the lack of resolution and the age-depth model uncertainties in the Chua1 core do not permit conclusions on the duration and continuity of the Tiwanaku mining activities. Further high-resolution studies on the peculiar Period of Tiwanaku would be of great interest. At the initiation of state formation and centralization of power on an unprecedented scale in the Lake Titicaca region, this civilization has extended its influence over much of the south-central Andes, processes partly rooted by ore exploitation and advanced metallurgical innovations.

\section{Declaration of Competing Interest}

The authors declare that they have no known competing financial interests or personal relationships that could have appeared to influence the work reported in this paper.

\section{Acknowledgments}

This work is a contribution to the PaleoBol project supported by a grant from IRD (BQR@ISTerre2016), and TRACISOMER supported by a grant from Labex OSUG@2020 (PI: S. Guédron: stephane. guedron@ird.fr). S. Guédron (ISTerre/IRD/UGA) is part of Labex OSUG@2020 (Investissements d'avenir ANR10 LABX56). S. Fritz and P. Baker were supported by grants from NSF (EAR-1338694) and the National Geographic Society (9299-13).

The authors thank Nadine Tisnerat-Laborde for the ${ }^{14} \mathrm{C}$ analyses acquired thanks to the ECHoMICADAS (Environnement, Climat, HOmme - MIcro CArbon DAting System) at the Laboratoire des Sciences du Climat et de l'Environnement (LSCE/IPSL). The authors thank the EDYTEM for the X-ray fluorescence analyses and the Laboratoire Souterrain de Modane for the gamma spectrometry facilities.

We greatly acknowledge Delphine Tisserand, Sarah Bureau and Sylvain Campillo for their help in chemical analysis (ICP-AES analysis) performed within the analytical chemistry platform of ISTerre (OSUG-France). We also thank Umeå Plant Science Center for making the Py-GC/MS available to us.

We wish to thank, J. Gardon, A. Terrazas, C. Gonzalez, N. Clavijo, L. Salvatierra, R. Rios, J.C. Salinas, A. Castillo, M. Claure (IRD Bolivia) and la Familia Catari (Don Ramon, Don Maximo, Don Eric, Don Ruben and Donia Maria) for their help and assistance during the field campaigns.

\section{Appendix A. Supplementary data}

Supplementary material related to this article can be found, in the online version, at doi:https://doi.org/10.1016/j.ancene.2021.100288.

\section{References}

Abbott, M.B., Wolfe, A.P., 2003. Intensive pre-incan metallurgy recorded by lake sediments from the Bolivian Andes. Science 301, 1893-1895.

Abbott, M.B., Binford, M.W., Brenner, M., Kelts, K.R., 1997. A $3500{ }^{14} \mathrm{C}$ yr highresolution record of water-level changes in Lake Titicaca, Bolivia/Peru. Quat. Res. 47, 169-180. 
Aitcheson, S.J., Harmon, R.S., Moorbath, S., Schneider, A., Soler, P., Soria-Escalante, E., Steele, G., Swainbank, I., Wörner, G., 1995. Pb isotopes define basement domains of the Altiplano, central Andes. Geology 23, 555-558.

Aldenderfer, M., Craig, N.M., Speakman, R.J., Popelka-Filcoff, R., 2008. Fourthousand-year-old gold artifacts from the Lake Titicaca basin, southern Peru. Proc. Natl. Acad. Sci. 105, 5002-5005.

Apolinarskaa, K., Pelechatyb, M., Pukaczc, A., 2011. Sedimentation by modern charophytes (Characeae): can calcified remains and carbonate $\mathrm{d}^{13} \mathrm{C}$ and $\mathrm{d}^{18} \mathrm{O}$ record the ecological state of lakes -a review. Studia Limnologica et Telmatologica 5, 55-66.

Arkush, E., 2011. Hillforts of the Ancient Andes: Colla Warfare, Society, and Landscape. Gainesville.

Baker, P.A., Seltzer, G.O., Fritz, S.C., Dunbar, R.B., Grove, M.J., Tapia, P.M., Cross, S.L., Rowe, H.D., Broda, J.P., 2001. The history of South American tropical precipitation for the past 25,000 years. Science 291, 640-643.

Balslev-Clausen, D., Dahl, T.W., Saad, N., Rosing, M.T., 2013. Precise and accurate $\delta^{13} \mathrm{C}$ analysis of rock samples using flash combustion-cavity ring down laser spectroscopy. J. Anal. At. Spectrom. 28, 516-523.

Bandy, M., 2013. Tiwanaku origins and the early development: the political and moral economy of a hospitality state. Visions of Tiwanaku 135-150.

Bandy, M.S., Vranich, A., Levine, A., 2013. Demographic dimensions of Tiwanaku urbanism. Advances in Titicaca basin archaeology 79-87.

Barre, J.P.G., Deletraz, G., Sola-Larrañaga, C., Santamaria, J.M., Bérail, S., Donard, O.F. X., Amouroux, D., 2018. Multi-element isotopic signature (C, N, Pb, Hg) in epiphytic lichens to discriminate atmospheric contamination as a function of land-use characteristics (Pyrénées-Atlantiques, SW France). Environ. Pollut. 243, 961-971.

Blaauw, M., 2010. Methods and code for' classical' age-modelling of radiocarbon sequences. Quat. Geochronol. 5, 512-518.

Bruel, R., Sabatier, P., 2020. Serac: A R package for shortlived radionuclide chronology of recent sediment cores. EarthArXiv..

Buchauer, M.J., 1973. Contamination of soil and vegetation near a zinc smelter by zinc, cadmium, copper, and lead. Environ. Sci. Technol. 7, 131-135.

Cesareo, R., Bustamante, A., Fabian, J., Zambrano, S., Alva, W., Chero, L., del Carmen Espinoza, M., Rodriguez, R., Seclen, M., Gutierrez, F., 2011. Evolution of precolumbian metallurgy from the North of Peru studied with a portable noninvasive equipment using energy-dispersive X-Ray fluorescence. J. Mater. Sci. Eng. B 1, 48.

Cohen, C.R., 2008. The Winds of Change: an Archaeometallurgical Study of Silver Production in the Porco-potosi Region, Southern Bolivia AD 1500-2000. University of London, University College London, United Kingdom).

Collis, J., 2003. The European Iron Age. Routledge.

Cooke, C.A., 2006. Lake Sediment Archives of Atmospheric Pollution From the Peruvian and Bolivian Andes. University of Pittsburgh.

Cooke, C.A., Abbott, M.B., Wolfe, A.P., Kittleson, J.L., 2007. A millennium of metallurgy recorded by lake sediments from Morococha, Peruvian Andes. Environ. Sci. Technol. 41, 3469-3474.

Cooke, C.A., Abbott, M.B., Wolfe, A.P., 2008a. Late-Holocene atmospheric lead deposition in the Peruvian and Bolivian Andes. Holocene 18, 353-359.

Cooke, C.A., Abbott, M.B., Wolfe, A.P., 2008b. Metallurgy in Southern South America. Encyclopaedia of the History of Science, Technology, and Medicine in Nonwestern Cultures. Springer, pp. 1658-1662.

Cooke, C.A., Balcom, P.H., Biester, H., Wolfe, A.P., 2009a. Over three millennia of mercury pollution in the Peruvian Andes. Proc. Natl. Acad. Sci. 106, 8830-8834.

Cooke, C.A., Wolfe, A.P., Hobbs, W.O., 2009b. Lake-sediment geochemistry reveals 1400 years of evolving extractive metallurgy at Cerro de Pasco, Peruvian Andes. Geology 37, 1019-1022.

Cooke, C.A., Balcom, P.H., Kerfoot, C., Abbott, M.B., Wolfe, A.P., 2011. Pre-Colombian mercury pollution associated with the smelting of argentiferous ores in the Bolivian Andes. Ambio A J. Hum. Environ. 40, 18-25.

Cooke, C.A., Hintelmann, H., Ague, J.J., Burger, R., Biester, H., Sachs, J.P., Engstrom, D. R., 2013. Use and legacy of mercury in the Andes. Environ. Sci. Technol. 47, 41814188.

Couture, N.C., Sampeck, K., 2003. Putuni: a history of palace architecture at tiwanaku. In: Kolata, A. (Ed.), Tiwanaku and Its Hinterland: Archaeology and Paleoecology of an Andean Civilization.. Smithsonian Institution, Washington (DC)/Chesham, pp. 226-263.

Covey, R.A., 2012. The development of society and status in the late prehispanic titicaca Basin (circa AD 1000-1535). In: Vranich, A., Klarich, E.A., Stanish, C. (Eds.), Advances in Titicaca Basin Archaeology - III, Memoirs.. Museum of Anthropology, University of Michigan, Ann Arbor, pp. 291-302.

Cross, S.L., Baker, P.A., Seltzer, G.O., Fritz, S.C., Dunbar, R.B., 2000. A new estimate of the Holocene lowstand level of Lake Titicaca, central Andes, and implications for tropical palaeohydrology. Holocene 10, 21-32.

Cruz, P.J., 2009. Tumbas, metalurgia y complejidad social en un pãramo del altiplano surandino. Pulacayo, Bolivia, ier milenio DC. Revista Andina 49, 71-104.

Cruz, P.J., Joinville Vacher, J., 2008. In: Cruz, P.J., Joinville Vacher, J., IRD (Eds.), Mina y metalurgia en los Andes del Sur desde la época prehispanica hasla el siglo XVII. IFEA, Sucre, pp. 352.

Davidson, J.P., de Silva, S.L., 1992. Volcanic rocks from the Bolivian Altiplano: insights into crustal structure, contamination, and magma genesis in the central Andes. Geology 20, 1127-1130.

Dejoux, C., 1992. In: IRD (Ed.), Lake Titicaca: a Synthesis of Limnological Knowledge. Boston: Kluwer Academic, Dordrecht (NLD).
Delaere, C., 2017. The Location of Lake Titicaca's coastal area during the Tiwanaku and Inca Periods: methodology and strategies of underwater archaeology. J. Marit. Archaeol. 12, 223-238.

Delaere, C., Capriles, J.M., Stanish, C., 2019. Underwater ritual offerings in the Island of the Sun and the formation of the Tiwanaku state. Proc. Natl. Acad. Sci. 116, 8233-8238.

Eichler, A., Gramlich, G., Kellerhals, T., Tobler, L., Schwikowski, M., 2016. Pb pollution from leaded gasoline in South America in the context of a 2000-year metallurgical history. Sci. Adv. 1, e1400196.

Eichler, A., Gramlich, G., Kellerhals, T., Tobler, L., Rehren, T., Schwikowski, M., 2017. Ice-core evidence of earliest extensive copper metallurgy in the Andes 2700 years ago. Sci. Rep. 7, 41855.

Elbaz-Poulichet, F., Guédron, S., Anne-Lise, D., Freydier, R., Perrot, V., Rossi, M., Piot, C., Delpoux, S., Sabatier, P., 2020. A 10,000-year record of trace metal and metalloid $(\mathrm{Cu}, \mathrm{Hg}, \mathrm{Sb}, \mathrm{Pb})$ deposition in a western Alpine lake (Lake Robert, France): Deciphering local and regional mining contamination. Quat. Sci. Rev. 228, 106076.

Engstrom, D.R., Fitzgerald, W.F, Cooke, C.A., Lamborg C.H., Drevnick, P.E., Swain, E. B., Balogh, S.J., Balcom, P.H., 2014. Atmospheric Hg emissions from preindustrial gold and silver extraction in the Americas: a reevaluation from lake-sediment archives. Environ. Sci. Technol. 48, 6533-6543.

Guédron, S., Grimaldi, C., Chauvel, C., Spadini, C., Grimaldi, M., 2006. Weathering versus atmospheric contributions to mercury concentrations in French Guiana soils. Appl. Geochem. 21, 2010-2022.

Guédron, S., Grangeon, S., Lanson, B., Grimaldi, M., 2009. Mercury speciation in tropical soil association; consequence of gold mining on $\mathrm{Hg}$ distribution in French Guiana. Geoderma 153, 331-346.

Guédron, S., Point, D., Acha, D., Bouchet, S., Baya, P.A., Molina, C.I., Tessier, E., Monperrus, M., Flores, M., Fernandez Saavedra, P., Espinoza, M.E., Heredia, C. Rocha, S., Groleau, A., Amice, E., Thebault, J., Alanoca, L., Duwig, C., Uzu, G., Lazzaro, X., Bertrand, A., Bertrand, S., Barbaud, C., Gibon, F.M., Ibanez, C., Zepita, C., Chauvaud, L., Amouroux, D., 2017. Mercury contamination level and speciation inventory in the hydrosystem of Lake Titicaca: current status and future trends. Environ. Pollut. 231, 262-270.

Guédron, S., Ledru, M.P., Escobar-Torrez, K., Develle, A.L., Brisset, E., 2018. Enhanced mercury deposition by Amazonian orographic precipitation: evidence from high-elevation Holocene records of the Lake Titicaca region (Bolivia). Palaeogeogr. Palaeoclimatol. Palaeoecol. 511, 577-587.

Guédron, S., Tolu, J., Brisset, E., Sabatier, P., Perrot, V., Bouchet, S., Develle, A.L., Bindler, R., Cossa, D., Fritz, S.C., 2019. Late Holocene volcanic and anthropogenic mercury deposition in the western Central Andes (Lake Chungará, Chile). Sci. Total Environ. 662, 903-914.

Guédron, S., Audry, S., Acha, D., Bouchet, S., Point, D., Condom, T., Heredia, C., Campillo, S., Baya, A., Groleau, A., Amice, E., Amouroux, D., 2020. Diagenetic production, accumulation and sediment-water exchanges of methylmercury in contrasted sediment facies of Lake Titicaca (Bolivia). Sci. Total Environ. doi: http://dx.doi.org/10.1016/j.scitotenv.2020.138088.

Guerrero, S., 2012. Chemistry as a tool for historical research: estimating the contraband of silver from Potosi and Oruro, 1576-1650. Bull. Hist. Chem. 37, $72-80$.

Guerrero, S., 2016. The history of silver refining in New Spain, 16c to 18c: back to the basics. Hist. Technol. 32, 2-32.

Heiri, O., Lotter, A.F., Lemcke, G., 2001. Loss on ignition as a method for estimating organic and carbonate content in sediments: reproducibility and comparability of results. J. Paleolimnol. 25, 101-110.

Hirao, Y., Ro, J.-H., 2013. Chemical composition and lead isotope ratios of bronze artifacts excavated in Cambodia and Thailand. Water Civilization. Springer, pp. 247-312.

Hogg, A.G., Hua, Q., Blackwell, P.G., Niu, M., Buck, C.E., Guilderson, T.P., Heaton, T.J., Palmer, J.G., Reimer, P.J., Reimer, R.W., 2013. SHCal13 Southern Hemisphere calibration, 0-50,000 years cal BP. Radiocarbon 55, 1889-1903.

Holtvoeth, J., Rushworth, D., Copsey, H., Imeri, A., Cara, M., Vogel, H., Wagner, T., Wolff, G.A., 2016. Improved end-member characterisation of modern organic matter pools in the Ohrid Basin (Albania, Macedonia) and evaluation of new palaeoenvironmental proxies. Biogeosciences 13, 795-816.

Hong, S., Candelone, J.-P., Patterson, C.C., Boutron, C.F., 1994. Greenland ice evidence of hemispheric lead pollution two millennia ago by Greek and Roman civilizations. Science 265, 1841-1843.

Hua, Q., Barbetti, M., Rakowski, A.Z., 2013. Atmospheric radiocarbon for the period 1950-2010. Radiocarbon 55, 2059-2072.

Janusek, J.W., 2008. Ancient Tiwanaku. Cambridge University Press, New York.

Kistler, R.C., Widmer, F., Brunner, P.H., 1987. Behavior of chromium, nickel, copper, zinc, cadmium, mercury, and lead during the pyrolysis of sewage sludge. Environ. Sci. Technol. 21, 704-708.

Lechtman, H., 1984. Technologies of Power, the Andean Case. Massachusetts Institute of Technology.

Lechtman, H., 2003. Tiwanaku period (Middle Horizon) bronze metallurgy in the Lake Titicaca Basin: a preliminary assessment. Tiwanaku and its hinterland 2. 404-497.

Lechtman, H., 2014. Andean Metallurgy in Prehistory, Archaeometallurgy in Global Perspective: Methods and Syntheses. Springer New York, New York, NY, pp. 361-422.

Lecoq, P., 1987. Caravanes de lamas, sel et échanges dans une communauté de Potosi, en Bolivie. Bulletin de l'Institut Français des Etudes andines 16,1-38. 
Longman, J., Veres, D., Finsinger, W., Ersek, V., 2018. Exceptionally high levels of lead pollution in the Balkans from the Early Bronze Age to the Industrial Revolution. Proc. Natl. Acad. Sci. 115, E5661-E5668.

Macfarlane, A.W. Lechtman, H.N., 2014. Andean ores, bronze artifacts, and lead isotopes: constraints on metal sources in their geological context. J. Archaeol. Method Theory 23, 1-72.

Macfarlane, A.W., Marcet, P., LeHuray, A.P., Petersen, U., 1990. Lead isotope provinces of the Central Andes inferred from ores and crustal rocks. Econ. Geol. 85, 18571880.

Manhes, G., Minster, J.F., Allègre, C.J., 1978. Comparative U-Th-Pb and Rb-Sr study of the Saint-Severin amphoterite: consequences for early solar system chronology. Earth Planet. Sci. Lett. 39, 14-24.

Metzger, P., Villarreal-Rosales, E., Casadevall, E., Couté, A., 1989. Hydrocarbons, aldehydes and triacylglycerols in some strains of the arace of the green alga Botryococcus braunii. Phytochemistry 28, 2349-2353.

Miller, J.R., Lechler, P.J., Hudson-Edwards, K.A., Macklin, M.G., 2002. Lead isotopic fingerprinting of heavy metal contamination, Rio Pilcomayo basin, Bolivia. Geochem. Explor. Environ. Anal. 2, 225-233.

Miller, J.R., Lechler, P.J., Mackin, G., Germanoski, D., Villarroel, L.F., 2007. Evaluation of particle dispersal from mining and milling operations using lead isotopic fingerprinting techniques, Rio Pilcomayo Basin, Bolivia. Sci. Total Environ. 384, 355-373.

Monna, F., Lancelot, Jl., Croudace, I.W., Cundy, A.B., Lewis, J.T., 1997. Pb isotopic composition of airborne particulate material from France and the southern United Kingdom: implications for Pb pollution sources in urban areas. Environ. Sci. Technol. 31, 2277-2286.

Nielsen, A.E., 1998. Tendencias De Larga Duracion En La Ocupacion Humana Del Altiplano De Lipez (Potosi, Bolivia). Universidad Nacional de Jujuy, San Salvador de Jujuy.

Nriagu, J.O., 1994. Mercury pollution from the past mining of gold and silver in the Americas. Sci. Total Environ. 149, 167-181.

Nriagu, J.O., 1996. A history of global metal pollution. Science 272, 223.

Núñez, A.L., 1987. El tráfico de metales en el área centro-sur andina: factos y expectativas. Cuadernos Instituto Nacional de Antropología 12, 73-105.

Osterberg, E., Mayewski, P., Kreutz, K., Fisher, D., Handley, M., Sneed, S., Zdanowicz, C., Zheng, J., Demuth, M., Waskiewicz, M., Bourgeois, J., 2008. Ice core record of rising lead pollution in the North Pacific atmosphere. Geophys. Res. Lett. 35.

Paul, D., Skrzypek, G., Forizs, In., 2007. Normalization of measured stable isotopic compositions to isotope reference scales-a review. Rapid Commun. Mass Spectrom. Int. J. Devoted Rapid Dissemination Minute Res. Mass Spectrom. 21, 3006-3014.

Pichat, S., Abouchami, W., Galer, S.J.G., 2014. Pb isotopic compositions database for South America, Patagonia, Asia, North Afria, Sahara, and Australia, in supplement to: Pichat, S et al. (2014): Lead isotopes in the Eastern Equatorial Pacific record quaternary migration of the South Westerlies. Earth Planet. Sci. Lett. 388, 293-305. doi:http://dx.doi.org/10.1016/j.epsl.2013.11.035.PANGAEA.

Reyss, J.L., Schimdt, S., Legeleux, F., Bonte, P., 1995. Large low background well type detectors for measurements of environmental radioactivity. Nucl. Instrum. Methods Phys. Res. B 391-397.
Rydberg, J., Cook, C.A., Tolu, J., Wolfe, A.P., Vinebrooke, R.D., 2020. An assessment of chlorophyll preservation in lake sediments using multiple analytical techniques applied to the annually laminated lake sediments of Nylandssjön. Journal of Paleolimnology in revision.

Schultze, C.A., Stanish, C., Scott, D.A., Rehren, T., Kuehner, S., Feathers, J.K., 2009. Direct evidence of 1,900 years of indigenous silver production in the Lake Titicaca Basin of Southern Peru. Proc. Natl. Acad. Sci. 106, 17280-17283.

Schultze, C.A., Huff, J.A., Rehren, T., Levine, A.R., 2016. The emergence of complex silver metallurgy in the Americas: a case study from the Lake Titicaca Basin of Southern Peru. Cambridge Archaeol. J. 26, 53-64.

Sillitoe, R.H., 2003. Iron oxide-copper-gold deposits: an Andean view. Miner. Depos. 38, 787-812.

Slemr, F., Seiler, W., Schuster, G., 1981. Latitudinal distribution of mercury over the Atlantic Ocean. J. Geophys. Res. Oceans 86, 1159-1166.

Theissen, K.M., Zinniker, D.A., Moldowan, J.M., Dunbar, R.B., Rowe, H.D., 2005. Pronounced occurrence of long-chain alkenones and dinosterol in a 25,000year lipid molecular fossil record from Lake Titicaca, South America. Geochim. Cosmochim. Acta 69, 623-636.

Thevenon, F., Guédron, S., Chiaradia, M., Loizeau, J.-L., Poté, J., 2011. (Pre-) historic changes in natural and anthropogenic heavy metals deposition inferred from two contrasting Swiss Alpine lakes. Quat. Sci. Rev. 30, 224-233.

Thompson, L.G., Mosley-Thompson, E., Bolzan, J.F., Koci, B.R., 1985. A 1500-year record of tropical precipitation in ice cores from the Quelccaya ice cap. Peru. Science 229, 971-973.

Thompson, L.G., Davis, M.E., Mosley-Thompson, E., Sowers, T.A., Henderson, K.A., Zagorodnov, V.S., Lin, P.N., Mikhalenko, V.N., Campen, R.K., Bolzan, J.F., 1998. A 25,000-year tropical climate history from Bolivian ice cores. Science 282, 1858 1864.

Tilton, G.R., Barreiro, B.A., 1980. Origin of lead in Andean calc-alkaline lavas, southern Peru. Science 210, 1245-1247.

Tolu, J., Gerber, L., Boily, J.-Fo., Bindler, R., 2015. High-throughput characterization of sediment organic matter by pyrolysis gas chromatography/mass spectrometry and multivariate curve resolution: a promising analytical tool in (paleo) limnology. Anal. Chim. Acta 880, 93-102.

Uglietti, C., Gabrielli, P., Cooke, C.A., Vallelonga, P., Thompson, L.G., 2015. Widespread pollution of the South American atmosphere predates the industrial revolution by 240 y. Proc. Natl. Acad. Sci. 112, 2349-2354.

Weeks, L., Keall, E., Pashley, V., Evans, J., Stock, S., 2009. Lead isotope analyses of Bronze Age copper-base artefacts from Al-Midamman, Yemen: towards the identification of an indigenous metal production and exchange system in the Southern Red Sea Region. Archaeometry 51, 576-597.

Weide, D.M., Fritz, S.C., Hastorf, C.A., Bruno, M.C., Baker, P.A., Guédron, S., Salenbien, W., 2017. A $6000 \mathrm{yr}$ diatom record of mid-to late Holocene fluctuations in the level of Lago Winaymarca, Lake Titicaca (Peru/Bolivia). Quat. Res. 88, 179-192.

Wörner, G., Moorbath, S., Harmon, R.S., 1992. Andean Cenozoic volcanic centers reflect basement isotopic domains. Geology 20, 1103-1106.

Yener, K.Ah., Sayre, E.V., Joel, E.C., Ozbal, H., Barnes, I.L., Brill, R.H., 1991. Stable lead isotope studies of Central Taurus ore sources and related artifacts from Eastern Mediterranean Chalcolithic and Bronze Age sites. J. Archaeol. Sci. 18, 541-577. 